\title{
Distinct chemical and mineralogical composition of Icelandic dust compared to northern African and Asian dust
}

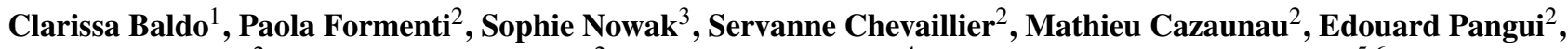 \\ Claudia Di Biagio $^{2}$, Jean-Francois Doussin ${ }^{2}$, Konstantin Ignatyev ${ }^{4}$, Pavla Dagsson-Waldhauserova ${ }^{5,6}$, \\ Olafur Arnalds $^{5}$, A. Robert MacKenzie ${ }^{1}$, and Zongbo Shi ${ }^{1}$ \\ ${ }^{1}$ School of Geography, Earth and Environmental Sciences, University of Birmingham, Birmingham, United Kingdom \\ ${ }^{2}$ LISA, UMR CNRS 7583, Université Paris-Est Créteil, Université de Paris, \\ Institut Pierre-Simon Laplace (IPSL), Créteil, France \\ ${ }^{3}$ Plateforme RX - UFR de Chimie, Université de Paris, Paris, France \\ ${ }^{4}$ Diamond Light Source, Didcot, Oxfordshire, United Kingdom \\ ${ }^{5}$ Agricultural University of Iceland, Keldnaholt, Reykjavik, Iceland \\ ${ }^{6}$ Faculty of Environmental Sciences, Czech University of Life Sciences Prague, Prague, Czech Republic
}

Correspondence: Zongbo Shi (z.shi@bham.ac.uk)

Received: 4 May 2020 - Discussion started: 28 May 2020

Revised: 31 August 2020 - Accepted: 7 September 2020 - Published: 12 November 2020

\begin{abstract}
Iceland is a highly active source of natural dust. Icelandic dust has the potential to directly affect the climate via dust-radiation interaction and indirectly via dust-cloud interaction, the snow/ice albedo effect and impacts on biogeochemical cycles. The impacts of Icelandic dust depend on its mineralogical and chemical composition. However, a lack of data has prevented an accurate assessment of the role of Icelandic dust in the Earth system. Here, we collected surface sediment samples from five major Icelandic dust hotspots. Dust aerosols were generated and suspended in atmospheric chambers, and $\mathrm{PM}_{10}$ and $\mathrm{PM}_{20}$ fractions were collected for further analysis. We found that the dust samples primarily consist of amorphous basaltic materials ranging from $8 \mathrm{wt} \%$ (from the Hagavatn hotspot) to $60 \mathrm{wt} \%-$ $90 \mathrm{wt} \%$ (other hotspots). Samples had relatively high total Fe content (10 wt \%-13 wt \%). Sequential extraction of Fe to determine its chemical form shows that dithionite $\mathrm{Fe}$ (Fe oxides such as hematite and goethite) and ascorbate $\mathrm{Fe}$ (amorphous $\mathrm{Fe}$ ) contribute respectively $1 \%-6 \%$ and $0.3 \%-1.4 \%$ to the total $\mathrm{Fe}$ in Icelandic dust. The magnetite fraction is $7 \%-15 \%$ of total $\mathrm{Fe}$ and $1 \%-2 \mathrm{wt} \%$ of $\mathrm{PM}_{10}$, which is orders of magnitude higher than in mineral dust from northern Africa. Nevertheless, about $80 \%-90 \%$ of the $\mathrm{Fe}$ is contained in pyroxene and amorphous glass. The initial $\mathrm{Fe}$ solubility (ammonium acetate extraction at $\mathrm{pH} 4.7$ ) is from $0.08 \%$ to
\end{abstract}

$0.6 \%$, which is comparable to low-latitude dust such as that from northern Africa. The Fe solubility at low pH (i.e. $\mathrm{pH} 2$ ) is significantly higher than typical low-latitude dust (up to $30 \%$ at $\mathrm{pH} 2$ after $72 \mathrm{~h}$ ). Our results revealed the fundamental differences in composition and mineralogy of Icelandic dust from low-latitude dust. We attribute these differences to the low degree of chemical weathering, the basaltic composition of the parent sediments and glacial processes. Icelandic dust contributes to the atmospheric deposition of soluble $\mathrm{Fe}$ and can impact primary productivity in the North Atlantic Ocean. The distinct chemical and mineralogical composition, particularly the high magnetite content ( $1 \mathrm{wt} \%-2 \mathrm{wt} \%)$, indicates a potentially significant impact of Icelandic dust on the radiation balance in the subpolar and polar regions.

\section{Introduction}

Airborne mineral dust has a major influence on the global climate. Depending on the chemical and mineralogical dust composition (together with the size distribution and shape), dust particles affect the radiation balance by scattering and absorbing the solar radiation and by scattering, absorbing and re-emitting terrestrial radiation (e.g. Haywood et al., 2003; Sokolik and Toon, 1999). This can produce cooling or warm- 
ing of the atmosphere and consequently alter the atmospheric circulation, stability and cloud cover (e.g. Arimoto, 2001; Carslaw et al., 2010; Choobari et al., 2014; Maher et al., 2010). Dust can also act as cloud condensation and ice nuclei, influencing cloud properties and lifetime (e.g. Tang et al., 2016; Atkinson et al., 2013). In the cryosphere, dust deposition on snow and ice reduces the surface albedo, altering the snow melting rate (e.g. Dumont et al., 2014; Meinander et al., 2014; Peltoniemi et al., 2015; Qian et al., 2015). Finally, dust can also affect the biogeochemical cycles of terrestrial and marine ecosystems by deposition of nutrients and pollutants (e.g. Jickells and Moore, 2015; Jickells et al., 2005; Kanakidou et al., 2018; Mahowald et al., 2010; Shi et al., 2012; Stockdale et al., 2016).

Natural dust is emitted from soil surfaces through wind erosion and is generally associated with desert dust from arid and semi-arid regions. However, significant dust events also occur in cold regions at high latitude (Bullard et al., 2016). In the Northern Hemisphere, high-latitude $\left(>60^{\circ} \mathrm{N}\right)$ dust sources include, for example, Alaska, Canada, Greenland, and Iceland and contribute about $3 \%$ to global dust emissions (Groot Zwaaftink et al., 2016).

Iceland is among the most active dust source areas in the world. Iceland has extensive sandy deserts subjected to intensive aeolian processes (Arnalds et al., 2001). The active aeolian areas cover $15000 \mathrm{~km}^{2}$ and include super active dust hotspots. These areas have the potential to generate millions of tonnes of dust during major dust storm events (Arnalds et al., 2016). Iceland experiences 34-135 dust events per year, which is comparable to dust-active areas in arid regions including northern Africa and China (Dagsson-Waldhauserova et al., 2014a). The dust can travel long distances and reach Europe and the high Arctic (Baddock et al., 2017; Moroni et al., 2018; Dordevic et al., 2019; Prospero et al., 2012; Groot Zwaaftink et al., 2016, 2017).

Iceland lies in the North Atlantic Ocean, just south of the Arctic Circle. Iceland is a volcanic hotspot along the northern end of the Mid-Atlantic Ridge and has intensive volcanic activity (Oskarsson, 1980). Around $10 \%$ of Iceland is covered by glaciers (Björnsson and Palsson, 2008). Volcanic activity within glaciers is common in Iceland (Jakobsson and Gudmundsson, 2008). Glacial flood plains contain fine glacial volcanic sediments that supply the Icelandic dust hotspots (Jensen et al., 2018; Arnalds, 2010; Arnalds et al., 2016). Sandy areas in Iceland have a dark surface and are often dominated by amorphous basaltic glass (Arnalds et al., 2001). Therefore, Icelandic cold deserts are different from deserts in arid continental areas such as Africa and Asia.

Arnalds et al. (2014) estimated that 30-40 Tg of Icelandic dust is deposited annually on land, glaciers and sea. The majority is deposited on land, and around $18 \%-35 \%$ reach the ocean. Icelandic dust can affect the climate via dust deposition on glaciers. Wittmann et al. (2017) observed that the deposition of small amounts of dust on the Vatnajökull ice cap, the largest ice cap in Iceland, caused a positive radiative effect and enhanced ice melting due to the reduced surface albedo. Outdoor experiments found that thin layers of volcanic deposits on the Vatnajökull ice cap accelerated snow melting as a result of the reduced surface albedo, while thick layers of volcanic deposits $(1.5-15 \mathrm{~mm})$ had insulating effects because of reduced heat conduction to the glacier surface (Dragosics et al., 2016; Möller et al., 2016, 2018). The "Soot on the Snow" experiments in 2013 investigated the effect of black carbon (BC) and volcanic sand deposited on snow (Meinander et al., 2014; Peltoniemi et al., 2015). The results showed that the volcanic sand from Iceland reduces the surface albedo and increases the melting rate of snow similarly to black carbon. Icelandic dust is strongly light absorbing (Zubko et al., 2019). Icelandic dust is also rich in iron (Fe) (e.g. Arnalds et al., 2014). The Fe speciation regulates the light absorption properties of mineral dust in the shortwave spectrum, as Fe oxide minerals strongly absorb solar radiation (Caponi et al., 2017; Derimian et al., 2008; Di Biagio et al., 2019; Engelbrecht et al., 2016; Formenti et al., 2014a; Lafon et al., 2006; Moosmuller et al., 2012; Sokolik and Toon, 1999). In addition, atmospheric deposition of soluble $\mathrm{Fe}$ to the ocean can stimulate primary productivity and enhance carbon uptake, consequently affecting the carbon budget and climate (e.g. Jickells et al., 2005). As a consequence, Icelandic dust contributes to the instantaneous radiative forcing (IRF) in the Arctic (Kylling et al., 2018), and it may influence the biogeochemical processes in the subpolar North Atlantic Ocean, which is seasonally Fe limited (Arnalds et al., 2014).

Icelandic dust effectively scavenges $\mathrm{SO}_{2}$ and can possibly participate in a variety of heterogeneous reactions in the atmosphere and thus influence the chemical balance of the atmosphere (Urupina et al., 2019). Icelandic dust is also a potential source of ice-nucleating particles (Paramonov et al., 2018). The increase in ice-nucleating particles may shorten the lifetime and lower the albedo of mixed-phase clouds (Vergara-Temprado et al., 2018), which have a significant impact on the energy budgets in the Arctic region (Boucher et al., 2013).

However, our knowledge on the chemical and mineralogical compositions of Icelandic dust is very limited, which prevents us from providing a more realistic estimation on their local and regional impacts.

Here we determine the chemical and mineralogical compositions of Icelandic dust from major dust source areas. In particular, we focus on $\mathrm{Fe}$ speciation as it determines the light-absorption properties in the shortwave spectrum. The fractional $\mathrm{Fe}$ solubility of Icelandic dust is also determined. The Icelandic dust composition and Fe solubility are compared to northern African and Asian dust. The potential direct radiative effect and the implications for primary productivity in the North Atlantic Ocean are also discussed. 


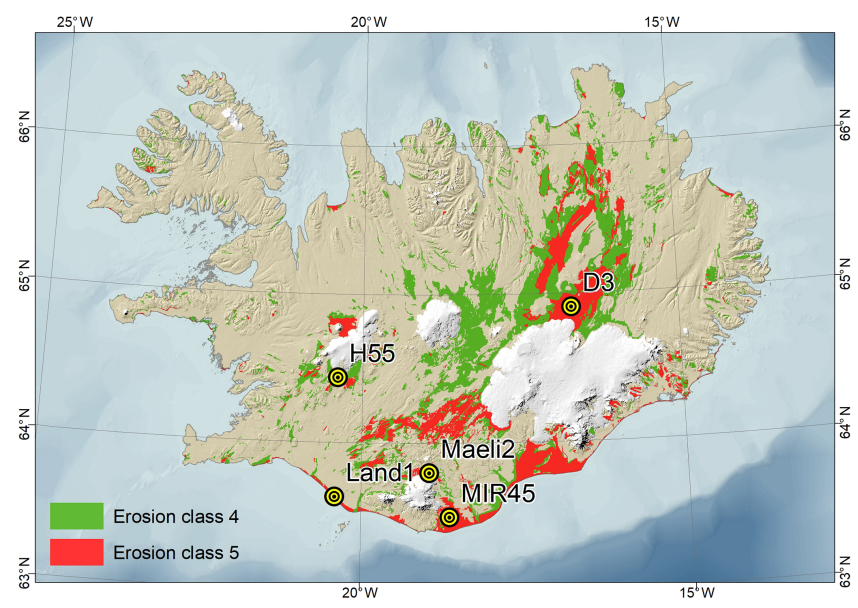

Figure 1. Surface sediment sampling sites and major dust hotspots. D3, Dyngjusandur hotspot; H55, Hagavatn hotspot; Land1, Landeyjarsandur; Maeli2, Mælifellssandur; MIR45, Mýrdalssandur. In green are the unstable sandy areas. In red are the very unstable sandy areas. Note that the map was prepared by Ólafur Arnalds using data created and owned by him at the Agricultural University of Iceland, older works (database housed by the Agricultural University of Iceland).

\section{Materials and methodology}

\subsection{Sample collection and experimental setup}

Surface sediment samples were collected from five major dust hotspots in Iceland: D3 (Dyngjusandur), H55 (Hagavatn), Land1 (Landeyjarsandur), Maeli2 (Mælifellssandur) and MIR45 (Mýrdalssandur), which are shown in Fig. 1. The coordinates of the sampling sites are reported in Table S1 in the Supplement. A comprehensive description of the sites is given in Arnalds (2010) and Arnalds et al. (2016). These extensive areas $\left(10-140 \mathrm{~km}^{2}\right)$ are subjected to intensive aeolian erosion due to frequent dust storms and significantly contribute to the total dust emissions from Iceland, which are of the order of 30-40 $\mathrm{Mt} \mathrm{yr}^{-1}$ (Arnalds et al., 2016).

In order to obtain dust particles which are representative of the particles emitted into the atmosphere, we resuspended the surface sediment samples in atmospheric chambers and collected the $\mathrm{PM}_{10}$ and $\mathrm{PM}_{20}$ fractions (particulate matter with aerodynamic diameters $<10$ and $<20 \mu \mathrm{m}$, respectively).

The $\mathrm{PM}_{10}$ samples were used for offline composition and mineralogy analyses. $\mathrm{PM}_{10}$ was collected using a custommade reactor schematically represented in Fig. S1 in the Supplement. The method in Di Biagio et al. (2017) was adopted to generate dust particles, allowing for the realistic generation of dust aerosols from parent soils. Firstly, the sediment samples were sieved to $<1 \mathrm{~mm}$ to remove the nonerodible fraction. Then, $15 \mathrm{~g}$ of sediments was placed in a Büchner flask and flushed with pure nitrogen for $10 \mathrm{~min}$ to eliminate gaseous contamination and residual water vapour.
The sample was then shaken for $5 \mathrm{~min}$ at $70 \mathrm{~Hz}$ on a sieve shaker (Retsch AS200) and injected into a glass manifold of approximately $1 \mathrm{~L}$ by nitrogen gas at $10 \mathrm{~L} \mathrm{~min}^{-1}$; air was pumped at a flow rate of $30 \mathrm{~L} \mathrm{~min}^{-1}$ into a $\mathrm{PM}_{10}$ sampling head (custom-made). The $\mathrm{PM}_{10}$ fraction was collected on $0.4 \mu \mathrm{m}$ polycarbonate filters and transferred into centrifuge tubes. The system was manually cleaned prior to each loading and flushed for $5 \mathrm{~min}$ with pure nitrogen to ensure an initial particle-free environment.

The $\mathrm{PM}_{20}$ fraction was collected using the large-scale atmospheric simulation chamber CESAM (French acronym for Experimental Multiphasic Atmospheric Simulation Chamber) (Wang et al., 2011). The CESAM simulation facility, made of stainless steel, consists of a $4.2 \mathrm{~m}^{3}$ multiinstrumented environmental chamber, which allowed us to measure the size distribution and the optical properties of the generated dust aerosols while collecting filter samples for offline analysis (Di Biagio et al., 2017, 2019). Dust particles were generated with the sieve shaker (Retsch AS200) using the same protocol as for the small reactor as in $\mathrm{Di} \mathrm{Bi}$ agio et al. (2017), and they were injected into the CESAM chamber by flushing a Büchner flask with nitrogen carrier gas at $10 \mathrm{~L} \mathrm{~min}^{-1}$ for $10 \mathrm{~min}$. The dust aerosol injected into CESAM was left suspended for about $10 \mathrm{~min}$ to allow the particle mass concentration inside the chamber to become spatially uniform. Dust particles corresponding to approximately the $\mathrm{PM}_{20}$ fraction were extracted from the chamber using custom-made filter samplers as in Caponi et al. (2017). Particles were collected by filtration on $0.4 \mu \mathrm{m}$ pore size polycarbonate filters of $37 \mathrm{~mm}$ diameter at $7 \mathrm{~L} \mathrm{~min}^{-1}$ for approximately $1 \mathrm{~h}$. The residence time of particles in the chamber depends on their size. As shown in Di Biagio et al. (2017), particles larger than $1 \mu \mathrm{m}$ have a lifetime of 20 $30 \mathrm{~min}$, while the lifetime of particles smaller than $1 \mu \mathrm{m}$ can exceed a day. A second filter sample was collected subsequently to the first one to verify if the chemical composition of the dust was dependent on size. No significant difference was observed (not shown). The relations between the composition, size distribution and optical properties of the aerosol dust will be the subject of a future paper.

\subsection{X-ray diffraction (XRD) analysis}

XRD was used to quantify the mineral phases present and to investigate the differences between the mineral fractions of dust aerosols $\left(\mathrm{PM}_{10}\right)$ and sediments. $\mathrm{PM}_{20}$ samples were not analysed because the mass of dust particles collected from CESAM was not sufficient for the XRD analysis. This is because the mass concentrations in the CESAM chamber are much lower compared to the custom-made reactor used for the $\mathrm{PM}_{10}$ collection. The analysis was carried out at the Université de Paris, Plateforme RX UFR - de Chimie, using a Panalytical Empyrean powder diffractometer equipped with a PIXcel detector fitted with a $\mathrm{Cu}$ anode tube $\left(\mathrm{K} \alpha_{1}=1.5406 \AA\right)$ operating at $45 \mathrm{kV}$ and $40 \mathrm{~mA}$. Diffrac- 
tograms were recorded in the $5-60^{\circ} 2 \theta$ range. The samples were placed on a flat silicon monocrystalline wafer, which was loaded on the sample holder, a reflection spinner $(1 \mathrm{~s}$ rotation time). The mineral identification was performed in Highscore Plus 3.0 (Degen et al., 2014) using the ICSD-Pan (Inorganic Crystal Structure Database) and COD (Crystallography Open Database) databases. The quantitative analysis of the mineral phases was conducted in MAUD (Material Analysis Using Diffraction). MAUD is an XRD program based on the Rietveld refinement method, which uses least-square procedures to minimise the differences between the observed and calculated diffractograms (Lutterotti et al., 1999). The phase files identified with Highscore Plus were loaded as references in MAUD. It is also possible to determine the proportion of amorphous phase with the Rietveld method (Lutterotti et al., 1998). Augite was chosen as reference for the amorphous phase, having an Fe content close to MIR45, which are the samples with largest proportion of amorphous glass. The Rietveld model refines $n-1$ phases. As the total is fixed to 100 , the last phase results from the subtraction of the sum of the $n$ refined phases. The analytical uncertainty is estimated by the software for the refined phases and represents the lower limit of the uncertainty of the proportion of each identified mineral phase.

The quality of the fitting was evaluated considering the $\chi^{2}$ calculated by the model close to one and by visually comparing the observed and calculated diffractograms to achieve a realistic chemical model (Toby, 2006). Small $\chi^{2}$ values can be obtained when a large percentage of the intensity comes from the background (Toby, 2006). For example, the estimated $\chi^{2}$ for H55 is relatively high (2.3-3.8), primarily due to missing minor mineral phases. However, H55 has the lowest fraction of amorphous material, and compared to the other samples having $\chi^{2}$ values very close to one, its diffraction intensities are considerably higher than the background signal.

\subsection{X-ray fluorescence (XRF) analysis}

$\mathrm{PM}_{10}$ and $\mathrm{PM}_{20}$ samples were analysed by wavelengthdispersive X-ray fluorescence (WD-XRF) to determine the elemental composition of the dust aerosols. The WD-XRF analyses were performed using a PW-2404 spectrometer by Panalytical available at LISA. Excitation X-rays are produced by a Coolidge tube $\left(I_{\max }=125 \mathrm{~mA}, V_{\max }=60 \mathrm{kV}\right)$ with a $\mathrm{Rh}$ anode. The primary $\mathrm{X}$-ray spectrum is controlled by inserting filters ( $\mathrm{Al}$, at different thickness) between the anode and the sample. Each element was analysed three times, with specific conditions (voltage, tube filter, collimator, analysing crystal and detector), lasting 8 to $10 \mathrm{~s}$.

Data were collected for 24 elements $(\mathrm{Cl}, \mathrm{S}, \mathrm{Ca}, \mathrm{Fe}, \mathrm{Na}$, $\mathrm{Mg}, \mathrm{Al}, \mathrm{Si}, \mathrm{P}, \mathrm{K}, \mathrm{Ti}, \mathrm{Mn}, \mathrm{Zn}, \mathrm{Cr}, \mathrm{V}, \mathrm{Ba}, \mathrm{Co}, \mathrm{Cu}, \mathrm{Nd}, \mathrm{Ni}, \mathrm{Sr}$, $\mathrm{Cd}, \mathrm{As}, \mathrm{Pb}$ ) using the SuperQ software. The elemental mass thickness $\left(\mu \mathrm{g} \mathrm{cm}^{-2}\right)$, which is the analysed elemental mass per unit surface, was obtained by comparing the sample Xray yields with those measured in the same geometry on a set of certified XRF calibration standards (Micromatter ${ }^{\mathrm{TM}}$ ). The uncertainty of the measured elemental concentrations is around $10 \%$ (Caponi et al., 2017).

Data are reported as weight percentage of element oxides (wt \%) calculated by dividing the elemental oxide mass ( $\mu \mathrm{g}$ ) by the total mass on filter $(\mu \mathrm{g})$. The elemental mass on filter $(\mu \mathrm{g})$ was first determined by multiplying the measured mass thickness by the ratio between the analysed surface area and the collection area, and it was then converted into elemental oxide mass. The total mass on filter was calculated as the sum of the mass of the oxides of the major crustal elements reported in Table 1. Fe is assumed to be as $\mathrm{Fe}_{2} \mathrm{O}_{3}$. We recognise that $\mathrm{Fe}$ (II) and $\mathrm{Fe}$ (III) can be found in the mineral phases (e.g. magnetite, augite) and in the amorphous glass, but the $\mathrm{Fe}(\mathrm{II}) / \mathrm{Fe}$ (III) ratio is not known.

In the XRF analysis, the concentration of light elements (atomic number $Z<19$ ), such as $\mathrm{Si}$ and $\mathrm{Al}$, can be underestimated due to self-absorption of the emitted fluorescence $\mathrm{X}$-ray in the individual particles when these exceed approximately $1 \mu \mathrm{m}$ in diameter. This is problematic when comparing elemental ratios such as $\mathrm{Fe} / \mathrm{Al}$ (Formenti et al., 2010). In this study, the concentrations of light-weight elements were corrected for self-attenuation effects according to Formenti et al. (2010).

\subsection{Chemical weathering index}

The degree of chemical weathering of Icelandic dust was calculated based on the elemental composition. This is important to evaluate the presence in the samples of secondary minerals such as clays. The chemical index of alteration (CIA) (Nesbitt and Young, 1984) was considered most suitable for the present datasets based on the chemical compositions. The CIA is interpreted as a measure of the degree of weathering of aluminium silicate minerals (in particular feldspars) into clay minerals. In this study, the CIA was calculated according to Price and Velbel (2003) using the molecular proportion of the element oxides, which were obtained by dividing the weight percentage of each oxide by the molecular weight of the oxide:

$$
\mathrm{CIA}=\frac{\mathrm{Al}_{2} \mathrm{O}_{3}}{\mathrm{Al}_{2} \mathrm{O}_{3}+\mathrm{CaO}+\mathrm{Na}_{2} \mathrm{O}+\mathrm{K}_{2} \mathrm{O}} \times 100 .
$$

CIA $\leq 50$ represents the optimum fresh value, while 100 is the optimum weathered value. The CIA uncertainty was estimated using the error propagation formula and is $\sim 14 \%$.

\subsection{X-ray absorption near edge structure (XANES) analysis}

To qualitatively examine the Fe speciation in the dust samples, XANES spectra at the Fe K-edge were collected at the Diamond Light Source beamline I18. A Si(111) doublecrystal monochromator was used in the experiments. The beam size was $400 \mu \mathrm{m} \times 400 \mu \mathrm{m}$. The XANES spectra were 
Table 1. Elemental oxide mass percentages, chemical index of alteration (CIA) and relevant elemental ratios in $\mathrm{PM}_{10}$ (custom-made reactor) and $\mathrm{PM}_{20}$ (CESAM chamber).

\begin{tabular}{|c|c|c|c|c|c|c|c|c|c|c|c|c|c|c|c|}
\hline \multirow[t]{2}{*}{ Sample } & \multirow[t]{2}{*}{ Size fraction } & \multicolumn{10}{|c|}{ Element oxide mass wt $\%$} & \multirow[t]{2}{*}{ CIA } & \multirow[t]{2}{*}{$\mathrm{Si} / \mathrm{Al}$} & \multirow[t]{2}{*}{$\mathrm{Fe} / \mathrm{Al}$} & \multirow[t]{2}{*}{$\mathrm{Ca} / \mathrm{Fe}$} \\
\hline & & $\mathrm{CaO}$ & $\mathrm{Fe}_{2} \mathrm{O}_{3}$ & $\mathrm{Na}_{2} \mathrm{O}$ & $\mathrm{MgO}$ & $\mathrm{Al}_{2} \mathrm{O}_{3}$ & $\mathrm{SiO}_{2}$ & $\mathrm{P}_{2} \mathrm{O}_{5}$ & $\mathrm{~K}_{2} \mathrm{O}$ & $\mathrm{TiO}_{2}$ & $\mathrm{MnO}$ & & & & \\
\hline D3 & $\mathrm{PM}_{10}$ & 11.6 & 16.3 & 2.3 & 4.9 & 13.7 & 47.5 & 0.2 & 0.5 & 2.7 & 0.3 & 35 & 3.06 & 1.58 & 1.38 \\
\hline Land1 & $\mathrm{PM}_{10}$ & 6.9 & 18.2 & 2.5 & 2.4 & 12.7 & 50.8 & 0.4 & 1.4 & 4.3 & 0.3 & 41 & 3.52 & 1.88 & 2.56 \\
\hline Maeli2 & $\mathrm{PM}_{10}$ & 8.5 & 18.4 & 2.4 & 3.9 & 12.7 & 47.7 & 0.3 & 0.9 & 4.9 & 0.3 & 38 & 3.31 & 1.92 & 2.13 \\
\hline MIR45 & $\mathrm{PM}_{10}$ & 8.6 & 18.8 & 2.6 & 4.0 & 11.4 & 47.4 & 0.4 & 0.9 & 5.5 & 0.4 & 35 & 3.68 & 2.18 & 2.14 \\
\hline Land1 & $\mathrm{PM}_{20}$ & 5.8 & 16.8 & 2.9 & 2.8 & 13.6 & 52.2 & 0.5 & 1.2 & 4.0 & 0.3 & 45 & 3.39 & 1.63 & 2.82 \\
\hline Maeli2 & $\mathrm{PM}_{20}$ & 7.6 & 17.6 & 2.5 & 3.9 & 13.1 & 49.2 & 0.3 & 0.8 & 4.7 & 0.2 & 41 & 3.32 & 1.78 & 2.26 \\
\hline MIR45 & $\mathrm{PM}_{20}$ & 8.3 & 18.8 & 2.8 & 4.0 & 11.7 & 47.9 & 0.4 & 0.9 & 5.0 & 0.3 & 36 & 3.61 & 2.11 & 2.22 \\
\hline
\end{tabular}

Note that the data uncertainty was estimated using the error propagation formula: $\sim 12 \%$ for the elemental oxide mass percentage and $\sim 14 \%$ for CIA and the element ratios.

collected from 7000 to $7300 \mathrm{eV}$ at a resolution varying from $0.2 \mathrm{eV}$ for $3 \mathrm{~s}$ in proximity to the Fe K-edge $(7100-7125 \mathrm{eV})$ to $5 \mathrm{eV}$ for $1 \mathrm{~s}$ from 7100 to $7300 \mathrm{eV}$. Powder samples were suspended in methanol and deposited on Kapton ${ }^{\circledR}$ tape. Filter samples were loaded without prior preparation. The analysis was repeated three times. We measured the XANES spectra of $\mathrm{PM}_{20}$ fractions and mineral standards, including hematite and goethite standards, magnetite, feldspar standards (Clay Mineral Society), natural pyroxene, and olivine. Data were processed using the Athena program, part of the software package Demeter (version 0.9.26) (Ravel and Newville, 2005). For comparison, we also collected the XANES spectra for mineral dust from the western Sahara and Mali regions (Shi et al., 2011b).

\subsection{Sequential extractions}

Sequential extractions of $\mathrm{Fe}$ were used to determine the content of Fe oxides in the $\mathrm{PM}_{10}$ fractions. The samples were suspended in an ascorbate solution buffered at $\mathrm{pH} 7.5$ to extract highly reactive amorphous Fe oxide-hydroxide (FeA) (Raiswell et al., 2008; Shi et al., 2009, 2011b). The ascorbate extractant was prepared by mixing a deoxygenated solution of $50 \mathrm{~g} \mathrm{~L}^{-1}$ sodium citrate and $50 \mathrm{~g} \mathrm{~L}^{-1}$ sodium bicarbonate, with $10 \mathrm{~g} \mathrm{~L}^{-1}$ ascorbic acid. Then, $30 \mathrm{mg}$ of dust was leached in $10 \mathrm{~mL}$ of ascorbate extractant continuously mixed for $24 \mathrm{~h}$. The solution was then filtered through $0.2 \mu \mathrm{m}$ membrane filters. The residue was subsequently suspended in a dithionite solution $\left(50 \mathrm{~g} \mathrm{~L}^{-1}\right.$ sodium dithionite in $0.35 \mathrm{M}$ acetic acid and $0.2 \mathrm{M}$ sodium citrate) buffered at $\mathrm{pH} 4.8$ for $2 \mathrm{~h}$ to extract crystalline Fe oxide-hydroxide, mainly goethite and hematite (FeD).

Dithionite and oxalate sequential extraction was performed to determine the content of iron associated with magnetite (FeM) in the samples (Poulton and Canfield, 2005). First, the dust particles were treated for $2 \mathrm{~h}$ with the citratebuffered dithionite solution to remove crystalline Fe oxidehydroxide. After filtration, the residue was leached for $6 \mathrm{~h}$ in a solution of $0.2 \mathrm{M}$ ammonium oxalate and $0.17 \mathrm{M}$ oxalic acid at $\mathrm{pH} 3.2$.

All the experiments were conducted at room temperature and in darkness. The sample solutions were continuously mixed on a rotary mixer and then filtered through $0.2 \mu \mathrm{m}$ membrane filters. The dissolved Fe concentration in the filtrates was measured using the ferrozine method (Viollier et al., 2000) and inductively coupled plasma optical emission spectrometry (ICP-OES) analysis for the solution containing oxalate. Each experiment was repeated three times. The range of relative standard deviations (rSDs) for each extract for each site are the following: FeA, 2\%-18\%; FeD, $1 \%-$ $11 \%$; and $\mathrm{FeM}, 2 \%-15 \%$, which have been considered the measurement uncertainties.

\subsection{Fe solubility and dissolution kinetics}

The initial Fe solubility $\left(\mathrm{Fe}_{\text {isol }}\right)$ of $\mathrm{PM}_{10}$ fractions was determined by extraction in $1.1 \mathrm{M}$ ammonium acetate solution at $\mathrm{pH} 4.7$ following the method in Baker et al. (2006). About $1 \mathrm{mg}$ of dust was weighed on polycarbonate filters and leached for $2 \mathrm{~h}$ in $10 \mathrm{~mL}$ of ammonium acetate solution. The solution was then filtered through $0.2 \mu \mathrm{m}$ membrane filters and acidified to $\mathrm{pH} 2$ before storage. Three replicates were performed for each sample (rSD 3\%-12\%).

The potential $\mathrm{Fe}$ solubility $\left(\mathrm{Fe}_{\mathrm{psol}}\right)$ was assessed through leaching experiments in sulfuric acid solution at $\mathrm{pH} 2$. Around $1.5 \mathrm{mg}$ of dust was weighed on polycarbonate filters and leached in $50 \mathrm{~mL}$ of $\mathrm{pH} 2$ sulfuric acid for $72 \mathrm{~h}$ to simulate atmospheric acid processing similar to the method in Shi et al. (2011a, 2015). The solution was continuously stirred in darkness at room temperature. A volume of $0.5 \mathrm{~mL}$ of sample solution was collected at fixed time intervals (2.5, $15,60 \mathrm{~min}$ as well as 2, 6, 24, 48 and $72 \mathrm{~h}$ after the dust sample was added) and filtered through $0.2 \mu \mathrm{m}$ syringe filters into $1 \mathrm{~mL}$ centrifuge tubes. Dissolution kinetics of a dust sample from Africa (Libya) showed a very good repeatability with 
a relative standard deviation at each sampling time ranging from $4 \%$ to $15 \%$.

All the experiments were conducted at room temperature and in darkness. The sample solutions were continuously mixed on a rotary mixer. The dissolved Fe concentration was measured using the ferrozine method (Viollier et al., 2000).

\subsection{Volume-average refractive index}

The volume-average refractive index was calculated to evaluate the effect of the dust compositions on the optical properties. Using the volume-average refractive index, we assume that the mineral phases in the dust samples are internally mixed, which can be different from the real conditions and may overestimate absorption (Formenti et al., 2014b):

$\tilde{n}(\lambda)=\sum_{j} f_{j} \times n_{j}(\lambda)$,

where $f_{j}=\frac{V_{j}}{V_{\text {tot }}}$ is the volume fraction of individual $j$ minerals in the dust samples, and $n_{j}$ is the corresponding refractive index. The mineral volumes $V_{j}\left(\mathrm{~cm}^{3}\right)$ are calculated as

$V_{j}=\frac{m_{j}}{\rho_{j}}$,

where $m_{j}=w_{j} \times m_{\text {tot }}$ is the mineral mass $(\mathrm{g}), w_{j}$ is the mineral mass fraction, $m_{\text {tot }}$ is the total mass of the sample $(\mathrm{g})$ and $\rho_{j}$ is the mineral density $\left(\mathrm{g} \mathrm{cm}^{-3}\right)$. The mineral mass fractions were obtained by combining the content of the silicate minerals and glass from the XRD analysis with the contents of FeM and FeD in $\mathrm{PM}_{10}$. The total mass is calculated as the sum of the element oxides mass from the XRF measurements. The densities of the crystalline phases are from http://webmineral.com/ (last access: 2 January 2020). The density of the amorphous glass was estimated for each sample as

$\rho_{\text {glass }}=\frac{\rho_{\text {dust }}-\sum_{j} w_{j \mathrm{CR}} \times \rho_{j \mathrm{CR}}}{w_{\text {glass }}}$,

where $\rho_{\text {dust }}$ is the density of the sample, $\rho_{j \mathrm{CR}}$ and $\mathrm{w}_{j \mathrm{CR}}$ are respectively the density and the mass fraction of the crystalline phases, and $w_{\text {glass }}$ is the mass fraction of glass. The density of the samples (fraction $<63 \mu \mathrm{m}$ ) was measured by a He pycnometer and varied from 2.80 to $3.1 \mathrm{~g} \mathrm{~cm}^{-3}$.

The volume-average refractive index was calculated at selected wavelengths $(470,520,590$ and $660 \mathrm{~nm})$. The reference complex refractive indices of the individual minerals are reported in Table $\mathrm{S} 2$; when necessary the original data were interpolated at the selected wavelengths. Since it was not possible to separate the relative contribution of hematite and goethite, we assumed two extreme scenarios: FeD is goethite and FeD is hematite. For hematite, we consider two reference complex refractive indices from Bedidi and Cervelle (1993) and Longtin et al. (1988) as in Formenti et al. (2014b). Also for magnetite we used two different reference indices from Querry (1985) and from Huffman and Stapp (1973).

\section{Results}

\subsection{Elemental composition}

Table 1 shows the results of the XRF analysis and also includes relevant elemental ratios. The $\mathrm{PM}_{10}$ fractions collected using the custom-made system and $\mathrm{PM}_{20}$ samples generated using CESAM have similar elemental compositions (Fig. S2). The difference between $\mathrm{PM}_{10}$ and $\mathrm{PM}_{20}$ in element oxide content $>1 \%$, including $\mathrm{CaO}, \mathrm{Fe}_{2} \mathrm{O}_{3}, \mathrm{Na}_{2} \mathrm{O}$, $\mathrm{MgO}, \mathrm{Al}_{2} \mathrm{O}_{3}, \mathrm{SiO}_{2}$ and $\mathrm{TiO}_{2}$, is within $16 \%$. For $\mathrm{Fe}_{2} \mathrm{O}_{3}$, $\mathrm{Al}_{2} \mathrm{O}_{3}$ and $\mathrm{SiO}_{2}$, which are the major element oxides in the dust samples, the relative differences in content are $<10 \%$. The $\mathrm{PM}_{10}$ and $\mathrm{PM}_{20}$ fractions have basaltic compositions like the parent material, with $\mathrm{SiO}_{2}$ representing 46\%-52\% of the total estimated mass and the sum of the alkali oxides $\left(\mathrm{Na}_{2} \mathrm{O}+\mathrm{K}_{2} \mathrm{O}\right.$ ) between $2 \%$ and $4 \%$ (see Fig. S3 in the Supplement). $\mathrm{Al}_{2} \mathrm{O}_{3}$ ranges between $11 \%$ in MIR45 and $18 \%$ in $\mathrm{H} 55$. $\mathrm{H} 55$ has the lowest $\mathrm{Si} / \mathrm{Al}$ ratio (2.3-2.4), while in the other samples $\mathrm{Si} / \mathrm{Al}$ is 3.1-3.7. The contents of $\mathrm{Fe}_{2} \mathrm{O}_{3}$ and $\mathrm{TiO}_{2}$ are relatively high. $\mathrm{Fe}_{2} \mathrm{O}_{3}$ is $14 \%-16 \%$ in $\mathrm{H} 55$ and D3, and $17 \%-19 \%$ in Land1, Maeli2 and MIR45. The $\mathrm{Fe} / \mathrm{Al}$ ratio is from 1 to 2.2 . $\mathrm{TiO}_{2}$ is around $2 \%-3 \%$ in $\mathrm{H} 55$ and D3, and 2\%-5.5\% in Land1, Maeli2 and MIR45. CaO is 6\%-9\% in Land1, Maeli2 and MIR45 and 10\%-12\% in $\mathrm{H} 55$ and D3. The Fe/Ca ratio is 1.2-1.4 in H55 and D3 and 2.1-2.8 in Land1, Maeli2 and MIR45. Compared to D3 and H55, Land1, Maeli2 and MIR45 have more Fe and Ti (titanium) but less $\mathrm{Ca}$.

\subsection{Mineralogical composition}

Table 2 reports the results of the XRD analysis. The mineralogy of Icelandic dust is compatible with the parent basaltic material. The mineral composition of $\mathrm{PM}_{10}$ is similar to the bulk sediments. In $\mathrm{H} 55$, the amorphous fraction is $8 \%$ in $\mathrm{PM}_{10}$ and $15 \%$ in the bulk sediments. This is significantly lower than the amorphous content observed in the rest of the samples, ranging from $60 \%$ to $90 \%$. MIR45 has the highest proportion of amorphous glass, around $90 \%$.

Ca-rich plagioclase (anorthite) and pyroxene (augite) are the dominant mineral phases. The content of plagioclase varies from around $4 \%$ in MIR45 to $46 \%$ in H55, while pyroxene is between $4 \%$ in MIR45 and $30 \%$ in H55. Olivine (forsterite) is only present in Land1 at around $7 \%$ and in $\mathrm{H} 55$ at $1.5 \%-1.6 \%$. K-feldspar (microcline) is also found in Land1 and H55, but the content of K-feldspar is higher in the $\mathrm{PM}_{10}$ fractions (around $9 \%$ in Land1 and 10\% in H55) compared to the bulk sediments ( $3 \%$ and $1 \%)$. XRD analysis identified (titano)magnetite in all the samples ( $>1 \%$ ), except for D3 (see Figs. S4-S8 in the Supplement).

\subsection{Fe speciation}

Figure 2 shows Fe phases in Icelandic dust from the sequential extractions. The total Fe (FeT) content is $10 \%-13 \%$, 
Table 2. Mineralogical composition of $\mathrm{PM}_{10}$ and sediments. Standard deviation (SD) values of the identified mineral phases are estimated by the MAUD software, except for anorthite, which is calculated using the error propagation formula.

\begin{tabular}{|c|c|c|c|c|c|c|c|c|c|}
\hline Samples & $\begin{array}{l}\text { Size } \\
\text { fraction }\end{array}$ & $\begin{array}{r}\text { Anorthite } \\
\text { wt \% (SD) }\end{array}$ & $\begin{array}{r}\text { Augite } \\
\text { wt } \% \text { (SD) }\end{array}$ & $\begin{array}{r}\text { Forsterite } \\
\text { wt } \% \text { (SD) }\end{array}$ & $\begin{array}{l}\text { Microcline } \\
\text { wt \% (SD) }\end{array}$ & $\begin{array}{r}\text { Quartz } \\
\text { wt } \% \text { (SD) }\end{array}$ & $\begin{array}{r}\text { Ti-magnetite } \\
\text { wt \% (SD) }\end{array}$ & $\begin{array}{r}\text { Glass } \\
\text { wt \% (SD) }\end{array}$ & $\chi^{2}$ \\
\hline D3 & $\mathrm{PM}_{10}$ & $14.9(0.9)$ & $13.4(0.2)$ & - & - & - & - & $71.7(0.9)$ & 1.0 \\
\hline H55 & $\mathrm{PM}_{10}$ & $43.3(1.7)$ & $29.7(0.4)$ & $7.3(0.3)$ & $10.3(0.6)$ & - & $1.3(0.1)$ & $8.1(1.5)$ & 2.3 \\
\hline Land1 & $\mathrm{PM}_{10}$ & $16.1(0.9)$ & $6.7(0.1)$ & $1.6(0.1)$ & $8.7(0.3)$ & $0.6(0.04)$ & $1.7(0.1)$ & $64.6(0.9)$ & 1.0 \\
\hline Maeli2 & $\mathrm{PM}_{10}$ & $8.9(1.2)$ & $8.2(0.2)$ & - & - & - & $1.6(0.1)$ & $81.3(1.2)$ & 0.9 \\
\hline MIR45 & $\mathrm{PM}_{10}$ & $3.6(2.3)$ & $3.6(0.1)$ & - & - & - & $1.1(0.1)$ & $91.7(2.4)$ & 0.8 \\
\hline D3 & Sediments & $13.0(0.9)$ & $11.1(0.2)$ & - & - & - & - & $75.9(0.9)$ & 1.0 \\
\hline H55 & Sediments & $46.1(1.5)$ & $29.7(0.4)$ & $6.5(0.3)$ & $1.3(0.3)$ & - & $1.2(0.1)$ & $15.2(1.3)$ & 3.8 \\
\hline Land1 & Sediments & $14.6(1.1)$ & $10.2(0.3)$ & $1.5(0.2)$ & $3.1(0.2)$ & $1.5(0.1)$ & $1.2(0.1)$ & $68.1(1)$ & 1.1 \\
\hline Maeli2 & Sediments & $9.3(1.3)$ & $7.1(0.2)$ & - & - & - & $1.4(0.1)$ & $82.2(1.3)$ & 0.8 \\
\hline MIR45 & Sediments & $4.3(2)$ & $4.1(0.2)$ & - & - & - & $1.7(0.1)$ & $89.9(2)$ & 0.8 \\
\hline
\end{tabular}

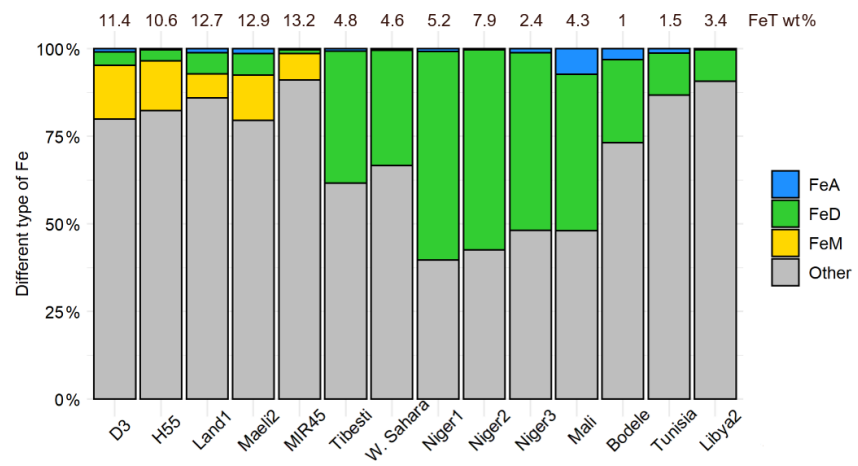

Figure 2. Percentages of ascorbate $\mathrm{Fe}(\mathrm{FeA})$, dithionite $\mathrm{Fe}(\mathrm{FeD})$, magnetite $\mathrm{Fe}(\mathrm{FeM})$ and other Fe to the total $\mathrm{Fe}(\mathrm{FeT})$ in Icelandic dust $\mathrm{PM}_{10}$ samples (this study) and African dust (Shi et al., 2011b). The data uncertainty was estimated using the error propagation formula: $12 \%-22 \%$ for FeA, $11 \%-16 \%$ for FeD, $12 \%-19 \%$ for FeM, and $\sim 11 \%$ for FeT. The original data are reported in Table S3 of the Supplement. Note that FeM was not measured in Shi et al. (2011b), but it is expected to be negligible in northern African dust (Lazaro et al., 2008; Moskowitz et al., 2016).

consistent with XRF analyses. The content of amorphous $\mathrm{Fe}$ $(\mathrm{FeA} / \mathrm{FeT})$ is $0.3 \%-0.4 \%$ in MIR45 and H55 and around $1 \%$ in D3, Land1 and Maeli2. Dithionite $\mathrm{Fe}(\mathrm{FeD} / \mathrm{FeT})$ is $1 \%$ in MIR45, 3\%-4\% in D3 and H55, and about $6 \%$ in Land1 and Maeli2. Magnetite (FeM/FeT) is $7 \%-8 \%$ in Land1 and MIR45 and around 13\%-15\% in D3, H55 and Maeli2. About $80 \%-90 \%$ of $\mathrm{Fe}$ is contained in other phases including minerals and amorphous glass.

The Fe K-edge XANES spectra of Icelandic dust have some common features (Fig. 3). In the pre-edge region, there is a main peak around $7114.4 \mathrm{eV}$ and a second less intense peak around $7112.7 \mathrm{eV}$. In the edge region, a main peak is observed around $7131.9 \mathrm{eV}$, but in $\mathrm{H} 55$ it is slightly shifted to $7131.4 \mathrm{eV}$. The presence of large quantities of amorphous material makes the quantitative analysis of the XANES spectra challenging. The presence of two peaks at 7112.7 and

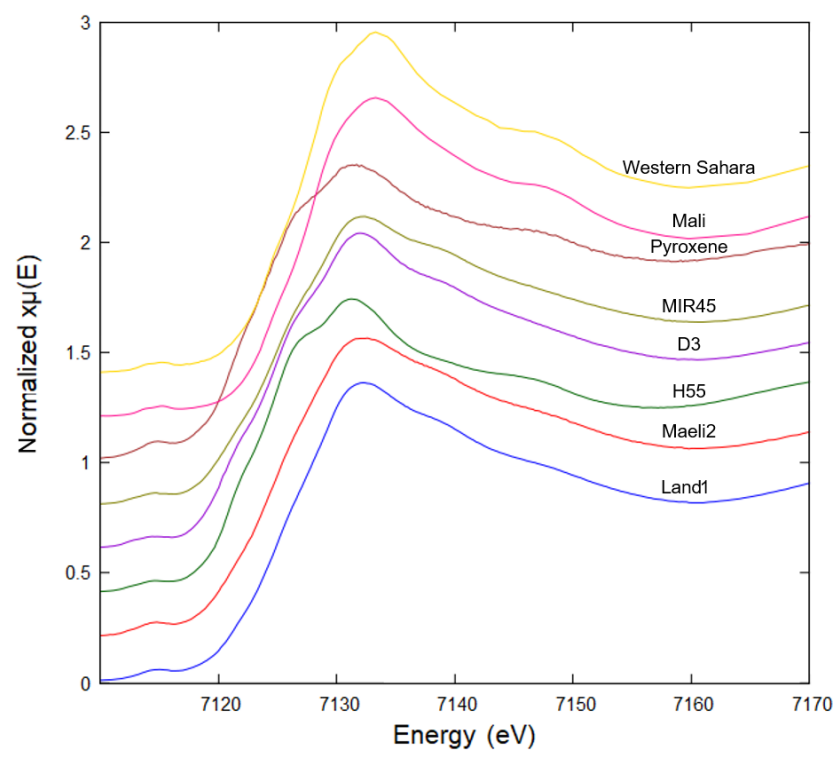

Figure 3. Fe K-edge XANES spectra of Icelandic dust, natural pyroxene from Iceland and African dust. The $y$ axis represents an arbitrary intensity.

7114.4 in the pre-edge region suggests that $\mathrm{Fe}$ is present both as $\mathrm{Fe}^{2+}$ and $\mathrm{Fe}^{3+}$ (Wilke et al., 2001). This agrees with the fact that magnetite, pyroxene and the glass phase contain $\mathrm{Fe}^{2+}$ and $\mathrm{Fe}^{3+}$. The composition and $\mathrm{Fe}$ speciation of the amorphous glass varies in the different samples. H55 represents the most crystalline samples (see above), and its spectral features are similar to the pyroxene standard. For all the other samples, the glass fraction is dominant and controls their spectral characteristics.

\subsection{Initial Fe solubility and dissolution kinetics}

The initial Fe solubility $\left(\mathrm{Fe}_{\text {isol }} / \mathrm{FeT}\right)$ is $0.08 \%-0.2 \%$, except in $\mathrm{D} 3$, which is as high as $0.6 \%$ (Fig. 4). We assessed the $\mathrm{Fe}$ dissolution kinetics of Icelandic dust through leaching ex- 


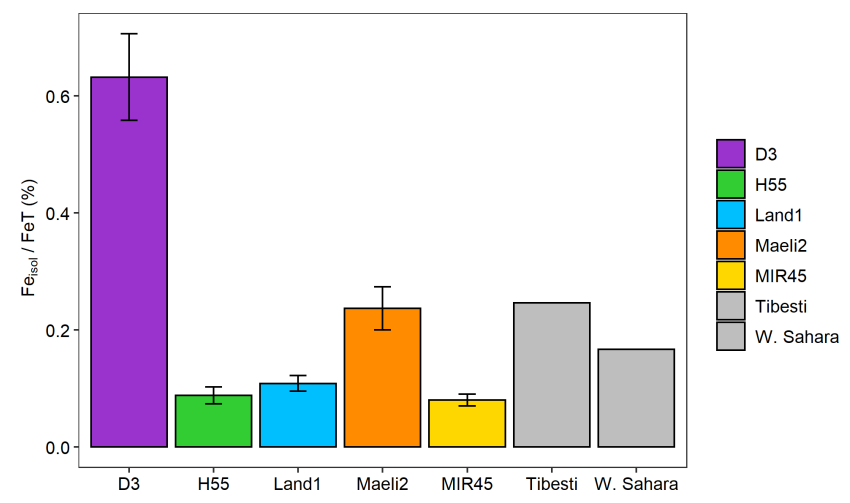

Figure 4. Initial $\mathrm{Fe}$ solubility $\left(\mathrm{Fe}_{\mathrm{isol}} / \mathrm{FeT}, \%\right)$ of Icelandic dust (this study). The data uncertainty was estimated using the error propagation formula. Data for African dust samples (Tibesti and western Sahara) were from Z. B. Shi et al. (2011).

periments in sulfuric acid at $\mathrm{pH} 2$. Figure 5 shows a fast dissolution rate at the beginning, suggesting the release of $\mathrm{Fe}$ from a highly reactive Fe phase. After $1-2 \mathrm{~h}$, the percentage of dissolved $\mathrm{Fe}$ increased at a slower rate, indicating that $\mathrm{Fe}$ solubilises from more stable phases (Shi et al., 2011a). After $72 \mathrm{~h}$ of leaching, the Fe solubility in D3 and Maeli2 was $30 \%$, up to 2 times higher than what was observed for the other Icelandic dust. The potential Fe solubility after $72 \mathrm{~h}$ $\left(\mathrm{Fe}_{\mathrm{psol}} / \mathrm{FeT}\right)$ was around $13 \%$ in MIR45, $17 \%$ in $\mathrm{H} 55$ and Land1, 26\% in Maeli2, and $29 \%$ in D3.

\section{Discussion}

Our data indicate that Icelandic dust has a basaltic composition with relatively high $\mathrm{Fe}_{2} \mathrm{O}_{3}$ and $\mathrm{TiO}_{2}$ contents (Table 1, Fig. S3). The principal crystalline mineral phases observed are Ca-rich plagioclase and pyroxene, while the amorphous fraction, mostly aluminosilicate glass, is $60 \%-90 \%$ (except for the Hagavatn hotspot, which is only $15 \%$ ). Glacial processes produce fine sediments (glacial flour), which accumulate into glaciofluvial floodplains where the dust hotspots are located (Arnalds, 2010; Arnalds et al., 2016). Our results are consistent with the composition of the volcanic systems supplying the dust hotspots: Bárðarbunga and Kverkfjöll volcanic systems (Dyngjusandur), Katla volcanic system (Mýrdalssandur, Mælifellssandur and Landeyjasandur), and Eldborgir and Skersli volcanic centres (Hagavatn) (Arnalds et al., 2016; Baratoux et al., 2011; Oladottir et al., 2008).

The large amorphous fraction found in Icelandic dust and in volcanic sandy deposits is related to the volcanic activity within glaciers (Baratoux et al., 2011). The rapid cooling of magma upon interaction with water prevents crystallisation and forms glass. Hyaloclastite deposits consisting of glass fragments are then eroded by the combined action of wind and glaciers. By contrast, sediments from the Hagavatn dust

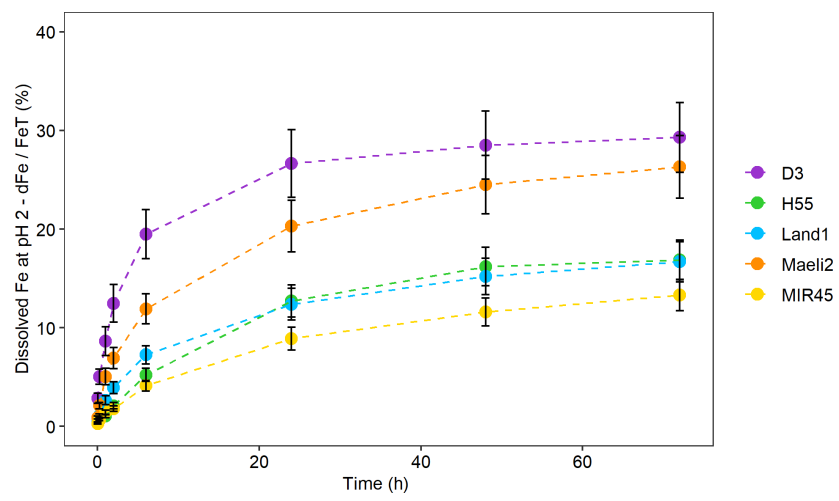

Figure 5. Fe dissolution kinetics at $\mathrm{pH}$ 2. The data uncertainty was estimated using the error propagation formula.

hotspots, south of the Langjökull glacier, are from the glacial erosion of lava flows (Baratoux et al., 2011). This material is more crystalline than hyaloclastites as the rate of cooling of magma is relatively slower.

\subsection{Mineralogical composition of Icelandic dust and parent sediments}

Our results show that the mineralogical compositions of $\mathrm{PM}_{10}$ are similar to the bulk sediments from the five dust hotspots. Mineralogical fractionation is observed in African and Asian dust as a result of size segregation during emission (e.g. Claquin et al., 1999; Jeong, 2008). Quartz and Kfeldspars are abundant in the soil silt fractions, while clay minerals are dominant in the clay fraction (Journet et al., 2014; Shi et al., 2005). Mineralogical fractionation is not evident in Icelandic dust, probably due to the low chemical weathering and the lack of larger mineral grains such as quartz, K-feldspar and clays. Only the more crystalline samples from Hagavatn showed some fractionation with respect to K-feldspar and glass, while the sediments from the other sites are derived from the glacial abrasion of hyaloclastite; thus, they tend to be more uniform.

Dagsson-Waldhauserova et al. (2015) reported the composition of dust deposited on snow after a snow-dust storm in Reykjavik. Dust was transported from the Skeiðarársandur and Hagavatn hotspots. About $75 \%$ of the dust particles were volcanic glass with basaltic composition. DagssonWaldhauserova et al. (2014b) investigated the composition of dust from the Mælifellssandur hotspot. The dust particles were primarily composed of basaltic glass $(80 \mathrm{wt} \%)$. The main mineral phases included plagioclases $(12 \mathrm{wt} \%)$, pyroxenes $(4.6 \mathrm{wt} \%)$ and olivine ( $2 \mathrm{wt} \%)$. Volcanic deposits supplying the major dust hotspots Dyngjusandur, Hagavatn, Landeyjarsandur, Mælifellssandur and Mýrdalssandur have basaltic compositions and relatively high $\mathrm{Fe}$ contents (over $10 \%$ ) (Baratoux et al., 2011; Oladottir et al., 2008). Basaltic glass is the major component (up to $90 \%$ ) in sediments from Dyngjusandur, Mælifellssandur and Mýrdalssandur (Bara- 
toux et al., 2011; Moroni et al., 2018). Baratoux et al. (2011) reported $10 \mathrm{wt} \%$ amorphous glass in volcanic sand from the Hagavatn hotspot area. Plagioclase, pyroxene and olivine are dominant minerals in sediments from Dyngjusandur, Hagavatn, Mælifellssandur and Mýrdalssandur (Baratoux et al., 2011; Moroni et al., 2018). (Titano)magnetite has also been identified in dust and sediments (Baratoux et al., 2011; Dagsson-Waldhauserova et al., 2014b, 2015; Moroni et al., 2018; Oladottir et al., 2008).

The chemical and mineralogical compositions of Icelandic dust determined in this study are comparable to those of rocks and volcanic sands from the Dyngjusandur and Hagavatn areas (Baratoux et al., 2011). The mineral phases observed in the sediments from Dyngjusandur, Mælifellssandur and Mýrdalssandur are also similar to those reported by Moroni et al. (2018).

\subsection{Comparison of Icelandic dust with northern African and Asian dust}

In Icelandic dust the $\mathrm{Si} / \mathrm{Al}$ ratio is $2.3-3.7$ and the $\mathrm{Fe} / \mathrm{Al}$ ratio is 1-2.2. In northern African and Asian dust, the $\mathrm{Si} / \mathrm{Al}$ ratio ranges between 1 and 7 (Scheuvens and Kandler, 2014). $\mathrm{Si} / \mathrm{Al}>10$ is reported in dust from Bodele Depression, which originates from Si-rich diatomite deposits (Scheuvens et al., 2013; Formenti et al., 2014b). In northern African dust, $\mathrm{Fe} / \mathrm{Al}$ is mainly $0.4-0.8$, with similar values reported for Asian dust (Formenti et al., 2011; Scheuvens and Kandler, 2014). Compared to northern African and Asian dust, Icelandic dust shows similar $\mathrm{Si} / \mathrm{Al}$ but higher $\mathrm{Fe} / \mathrm{Al}$ ratio.

$\mathrm{TiO}_{2}$ catalyses heterogeneous photochemical reactions of atmospheric trace gases including $\mathrm{SO}_{2}, \mathrm{NO}_{2}, \mathrm{VOC}$ and $\mathrm{O}_{3}$ and contributes to the chemical balance of the atmosphere (Chen et al., 2012). In northern African and Asian dust, $\mathrm{TiO}_{2}$ is around $1 \%$ (e.g. Formenti et al., 2014b; Jeong, 2008; Shi et al., 2011b). In Icelandic dust, the element oxide concentration of Ti is relatively high $(2 \%-5.5 \%)$, although Ti can exist in other forms not just as $\mathrm{TiO}_{2}$ minerals (anatase and rutile). Ti may be present in magnetite and aluminosilicate minerals (e.g. augite) or in the amorphous glass.

A comparison of our results for the $\mathrm{PM}_{10}$ fraction to northern African desert dust (Shi et al., 2011b) and Asian dust (Jeong, 2008) is provided in Fig. 6. The principal minerals in Icelandic dust are $\mathrm{Ca}$-rich plagioclase and pyroxene, with around $60 \%-90 \%$ of aluminosilicate glass. The mineral composition of Icelandic dust is therefore very different from northern African or Asian dust that derives from very different environments, which are composed mainly of quartz, feldspars, calcite and clays (Avila et al., 1997; Formenti et al., 2014b; Jeong, 2008; Jeong et al., 2016; Kandler et al., 2009; Scheuvens et al., 2013; Shao et al., 2007; Shi et al., 2005, 2011b).

The Fe mineralogy of Icelandic dust also differs significantly from northern African and Asian dust (Fig. 2). The total Fe content in Icelandic dust (10\%-13\%) is higher than (a) MIR45

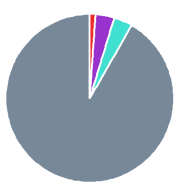

(b) Land1

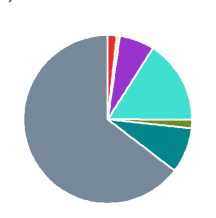

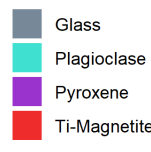

Ti-Magnetite

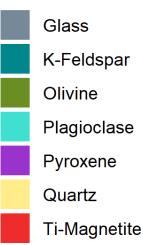

(c) African desert dust

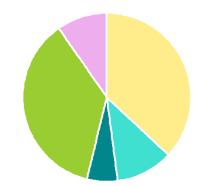

(d) Asian dust

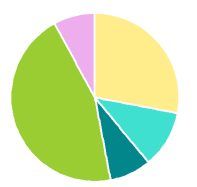

Carbonates

Clay

K-Feldspar

Plagioclase Quartz

Carbonates Clay K-Feldspar Plagioclase Quartz
Figure 6. (a-b) Mineralogy of Icelandic dust (MIR45 and Land1; $\mathrm{PM}_{10}$ ). (c) Mineral composition of northern African desert dust $\left(\mathrm{PM}_{20}\right)$, representing the average bulk composition by X-ray diffraction of Tibesti, western Sahara, Niger and Mali samples (Shi et al., 2011b). (d) Mineral composition of Asian dust ( $\left.\mathrm{PM}_{10}\right)$; average bulk composition by X-ray diffraction of dust from arid regions in Mongolia and northern China collected in Seoul (South Korea) during eight dust events in 2003-2005 (Jeong et al., 2008).

in northern African dust (1\%-8\%). In northern African and Asian dust, $\mathrm{Fe}$ is primarily as clay minerals and Fe oxides (e.g. Formenti et al., 2014b; Shi et al., 2011b; Lafon et al., 2006; Lu et al., 2017; Takahashi et al., 2011); in particular, goethite is dominant among the crystalline Fe oxidehydroxide (Formenti et al., 2014b; Lu et al., 2017). Icelandic dust has comparable amorphous $\mathrm{Fe}(\mathrm{FeA})$ content to northern African dust but higher magnetite and lower goethite and hematite (FeD) contents. Existing observations show that the magnetite content in African dust is generally below $0.1 \mathrm{wt} \%$ or not detectable (Lazaro et al., 2008; Moskowitz et al., 2016). Moskowitz et al. (2016) reported $0.6 \mathrm{wt} \%$ magnetite in surface sediments $\left(\mathrm{PM}_{63}\right)$ collected in proximity to the Tibesti volcanic system based on magnetic measurements. The content of magnetite reported in Asian dust source regions is in the range $0.1 \mathrm{wt} \%-0.8 \mathrm{wt} \%$ from magnetic measurements and XRD analysis (Jia et al., 2019; Maher et al., 2009; Song et al., 2014). Crusius et al. (2011) reported $0.2 \mathrm{wt} \%$ of magnetite in glacial dust from the Copper River valley. In Icelandic dust, the magnetite content estimated from XRD measurements and sequential extractions is $1 \mathrm{wt} \%-2 \mathrm{wt} \%$.

Magnetite and to a lesser extent hematite are common in magmatic rocks (Cornell and Schwertmann, 2003). Basalts have the highest magnetite content (Cornell and Schwertmann, 2003), which explains the high magnetite content in Icelandic dust. Hematite, goethite and ferrihydrite are more likely to form during weathering (Cornell and Schwertmann, 2003). Shi et al. (2011b) observed that the content of FeA and $\mathrm{FeD}$ in mineral dust from northern Africa was variable and dependent on the degree of weathering. The calculated CIA for Icelandic dust is below 50 (i.e. 35-45 in Table 1), 


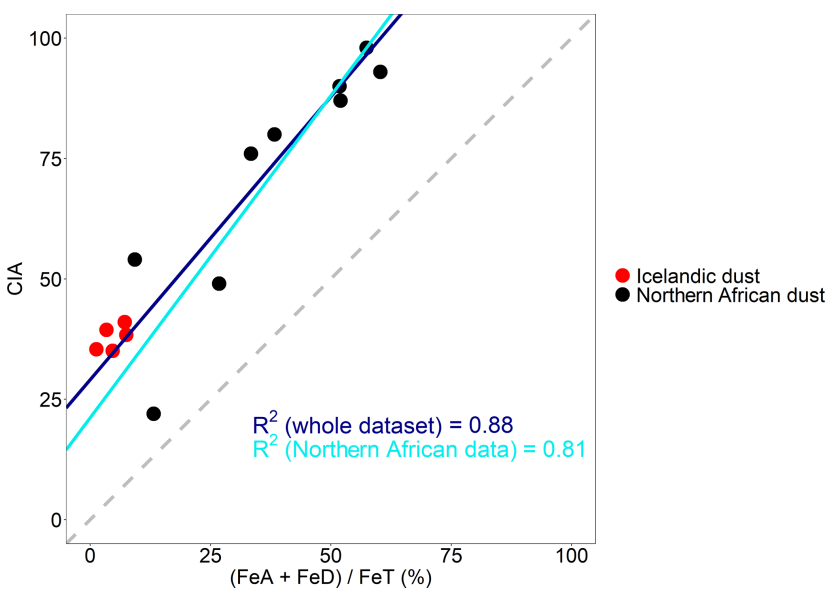

Figure 7. Correlation of the chemical index of alteration (CIA) with $(\mathrm{FeA}+\mathrm{FeD}) / \mathrm{FeT}(\%)$ performed using the standard major axis regression. Data for African dust are from Shi et al. (2011b). The regression line in blue was calculated including the whole dataset: Icelandic dust (this study) and northern African dust (Shi et al., 2011b). The regression line in light blue was calculated using only the northern African dust data (Shi et al., 2011b).

indicating a low degree of weathering. The dust hotspots in Iceland are characterised by the continuous input of material by glaciofluvial processes that prevents the alteration of minerals and the formation of soil (Arnalds, 2015).

Figure 7 shows the variation of CIA against $(\mathrm{FeA}+$ $\mathrm{FeD} / \mathrm{FeT}$ for both Icelandic dust and northern African dust (Shi et al., 2011b). Icelandic dust is weakly weathered and has low CIA and $(\mathrm{FeA}+\mathrm{FeD}) / \mathrm{FeT}$. By contrast, desert dust in northern Africa tends to be more weathered and consequently has higher CIA and $(\mathrm{FeA}+\mathrm{FeD}) / \mathrm{FeT}$. Having plotted the data from Shi et al. (2011b) together with the data from this study, the positive correlation between CIA and $(\mathrm{Fe} \mathrm{A}+\mathrm{FeD}) / \mathrm{FeT}$ is maintained. In summary, our results are consistent with the findings in Shi et al. (2011b) and suggest that the low contents of FeA and FeD observed in the samples is related to the low degree of weathering.

The XANES Fe K-edge spectra of Icelandic dust are also quite different from those of the northern African dust (Fig. 3). The spectra of the two African samples (western Sahara and Mali) have a clear double peak in the pre-edge region at around 7113.9 and $7115.2 \mathrm{eV}$ and a main peak in the edge region at around $7133.3 \mathrm{eV}$. This difference is consistent with the difference in Fe mineralogy reported above.

\subsection{Factors controlling Fe solubility in Icelandic dust}

The initial fractional Fe solubility observed in mineral dust from northern Africa and Asia is generally below $0.5 \%$ (Desboeufs et al., 2005; Oakes et al., 2012; Schroth et al., 2009; Z. B. Shi et al., 2011). In this study, the initial Fe solubility $\left(\mathrm{Fe}_{\text {isol }} / \mathrm{FeT}\right)$ of Icelandic dust is determined through ammonium acetate extraction at pH 4.7 (Baker et al., 2006), as in Z. B. Shi et al. (2011). Icelandic dust $\mathrm{Fe}_{\text {isol }} / \mathrm{FeT}$ varies from $0.08 \%$ to $0.6 \%$, which is comparable to $\mathrm{Fe}_{\text {isol }} / \mathrm{FeT}$ in African dust (around $0.2 \%$ ) in Z. B. Shi et al. (2011) (Fig. 4).

Icelandic dust has a similar origin to volcanic ash. Achterberg et al. (2013) observed an initial fractional Fe solubility of $0.04 \%-0.14 \%$ for ash from the 2011 eruption of the volcano Eyjafjallajökull (leaching in deionised water). Frogner et al. (2001) and Jones and Gislason (2008) reported relatively high initial fractional $\mathrm{Fe}$ solubility for ash from the 2000 eruption of the volcano Hekla, $2.5 \%$ for $44-74 \mu \mathrm{m}$ particle sizes and $0.6 \%$ for $45-125 \mu \mathrm{m}$ particle sizes (leaching in seawater). For the same volcano, Olgun et al. (2011) observed an initial fractional Fe solubility of $0.004 \%$ in the ash from the eruption in 1947 (leaching in seawater). The initial fractional $\mathrm{Fe}$ solubility of volcanic ash primarily depends on its surface properties determined by the eruption conditions, which can be very different from the bulk composition controlled by the source magma (Maters et al., 2017). The interaction of the ash with volcanic gases, mainly $\mathrm{HCl}, \mathrm{SO}_{2}$ and $\mathrm{HF}$, within the eruption plume (plume processing) enhances the dissolution of the ash surface and the $\mathrm{Fe}$ mobilisation (e.g. Ayris and Delmelle, 2012; Duggen et al., 2010). As the Fe speciation on the ash surface is determined by the eruption history, the Fe dissolution behaviour can vary significantly, even for ash emitted from the same volcano (Maters et al., 2017). After deposition, the ash undergoes further processing, which modifies its surface properties, and consequently the Fe speciation in freshly emitted ash may be different from the Icelandic volcanic dust. The range of initial fractional $\mathrm{Fe}$ solubility observed for volcanic ash from Iceland is quite large $(0.004 \%-2.5 \%)$. Although both Hekla and Eyjafjallajökull volcanoes have andesitic compositions (e.g. Frogner et al., 2001; Olgun et al., 2011), the initial Fe solubility of Icelandic dust still lies within this range.

Icelandic dust is strongly influenced by glacial processes. The FeA and $\mathrm{FeD}$ contents in Icelandic dust are similar to what were measured by Raiswell et al. (2016) in ice-hosted sediments: $0.03 \mathrm{wt} \%-0.2 \mathrm{wt} \%$ for $\mathrm{FeA}$ and $0.04 \mathrm{wt} \%-0.7 \mathrm{wt} \%$ for FeD. Previous research investigated the initial fractional $\mathrm{Fe}$ solubility of dust from glacial sediments in the Copper River valley, an important source of $\mathrm{Fe}$ for the Gulf of Alaska, which is Fe limited (Crusius et al., 2011; Schroth et al., 2009, 2017). Glacial dust and sediments showed high initial fractional Fe solubility, which was associated with a low degree of chemical weathering (Schroth et al., 2009, 2017). The initial fractional Fe solubility reported for the glacial dust from the Copper River valley is $1.4 \%$ (multiple leaches in Milli-Q water), 2-14 times higher than the initial Fe solubility observed for Icelandic dust. Mineralogy and Fe speciation control the Fe solubility in dust particles (Cwiertny et al., 2008; Fu et al., 2010; Journet et al., 2008; Schroth et al., 2009; Shi et al., 2011a). Although different methods were used, leading to uncertainties when comparing the results (Meskhidze et al., 2016), the large differences in initial fractional Fe solubility observed between the 
Icelandic dust and the glacial dust from the Copper River valley here is more likely due to the distinctive mineralogy and Fe speciation. Instead, measurements conducted on snow pits from Roosevelt Island (Antarctica) reported similar initial fractional $\mathrm{Fe}$ solubility to the Icelandic dust samples, around $0.7 \%$ (dissolved Fe in snowmelt) (Winton et al., 2016).

Icelandic dust composition is different from northern African and Asian dust, but they have similar initial Fe solubility. To better understand the factors controlling the $\mathrm{Fe}$ solubility in Icelandic dust, we investigated the Fe dissolution kinetics at low $\mathrm{pH}$. Icelandic dust showed a positive correlation between the potential $\mathrm{Fe}$ solubility $\left(\mathrm{Fe}_{\mathrm{psol}} / \mathrm{FeT}\right.$, defined as the fractional solubility after $72 \mathrm{~h}$ of dissolution at $\mathrm{pH} 2$ sulfuric acid) and the content of pyroxene and magnetite, when the fraction of amorphous materials is significant $(60 \%-90 \%)$ (Fig. S9 of the Supplement). But H55 weakens the overall correlation (Fig. S9). This could be explained by the significantly higher degree of crystallinity $(8 \%-15 \%)$ observed in $\mathrm{H} 55$, which affects the reactivity and Fe speciation in the sample. The degree of crystallinity may directly impact the $\mathrm{Fe}$ solubility, as amorphous materials are generally more reactive than the crystalline forms with same composition (Wolff-Boenisch et al., 2006). However, there is no apparent correlation between the $\mathrm{Fe}_{\mathrm{psol}}$ and the amorphous glass content, which was also observed for volcanic ash (Maters et al., 2017). This is because Icelandic dust consists of a mixture of crystalline minerals and glass, and the proportion of glass and its compositions vary in the different samples resulting in different solubility (Maters et al., 2017). The Fe minerals in Icelandic dust are mainly pyroxene and magnetite, and there is a minor contribution from olivine, hematite, goethite and ferrihydrite. Overall, the low degree of weathering and low crystallinity are responsible for the high potential Fe solubility in the samples.

Figure 8 shows that Icelandic dust $\mathrm{Fe}_{\mathrm{psol}} / \mathrm{FeT}$ is significantly higher than what was observed for intensively weathered desert dust such as in Niger, Tibesti and western Sahara samples (Shi et al., 2011b). $\mathrm{Fe}_{\mathrm{psol}} / \mathrm{FeT}$ in D3 and Maeli2 is about $30 \%$. In H55, Land1 and MIR45, $\mathrm{Fe}_{\mathrm{psol}} / \mathrm{FeT}$ is $13 \%-16 \%$, which is comparable to the African samples Bodele and Tunisia. These samples are from weakly weathered palaeolake sediments. Adding all the new data in this study to the data from Shi et al. (2011b) generates an inverse relationship between the degree of weathering and $\mathrm{Fe}_{\mathrm{psol}} / \mathrm{FeT}$ (Fig. 8), which is consistent with the finding in Shi et al. (2011b).

\subsection{Implications for the soluble Fe deposition to the ocean}

The subpolar North Atlantic Ocean including the Iceland Basin is seasonally Fe limited (Moore et al., 2006; Nielsdottir et al., 2009; Ryan-Keogh et al., 2013). Achterberg et al. (2013) reported that deposition of volcanic ash from the 2010 Eyjafjallajökull eruption caused a significant perturba-

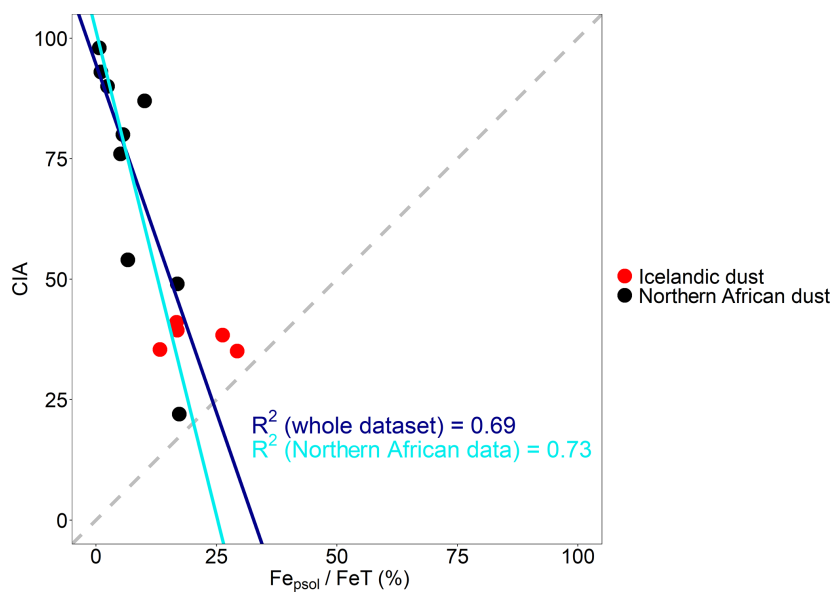

Figure 8. Correlation of the chemical index of alteration (CIA) with $\mathrm{Fe}_{\mathrm{psol}} / \mathrm{FeT}(\%)$ performed using the standard major axis regression. The regression line in blue was calculated including the whole dataset: Icelandic dust (this study) and northern African dust (Shi et al., 2011b). The regression line in light blue was calculated using only the northern African dust data (Shi et al., 2011b).

tion to the biogeochemistry of the Iceland Basin. Elevated dissolved Fe concentration and nitrate depletion were observed locally followed by an early spring bloom (Achterberg et al., 2013). This suggests that additional Fe inputs to the subpolar North Atlantic Ocean has the potential to perturb the biogeochemical cycling of Fe and primary production in the surface ocean.

Here we calculated the deposition of soluble $\mathrm{Fe}$ to the North Atlantic Ocean based on the total Fe deposition estimated in Arnalds et al. (2014), which is $0.56-1.38 \mathrm{Tg} \mathrm{yr}^{-1}$. The initial Fe solubility of Icelandic dust reported in this study varies from $0.08 \%$ to $0.2 \%$ for the dust hotspots in southern and central Iceland to $0.6 \%$ for Dyngjusandur in NE Iceland. As $90 \%$ of the dust reaching the ocean is from the southern coast of Iceland (Arnalds et al., 2014), a fractional Fe solubility of $0.13 \%$, the average of the dust hotspots in southern Iceland, is used in the calculation. The estimated soluble Fe deposition from Icelandic dust to the ocean is approximatively $0.73-1.79 \mathrm{Gg} \mathrm{yr}^{-1}$. This suggests that Icelandic dust contributes to around $0.3-0.7 \%$ of the global annual deposition flux of soluble Fe to the ocean (Myriokefalitakis et al., 2018).

\subsection{Implications for the direct radiative effect}

Kylling et al. (2018) estimated that in 2012 the instantaneous radiative forcing (IRF) of Icelandic dust in the Arctic was $0.02 \mathrm{~W} \mathrm{~m}^{-2}$ at the bottom of the atmosphere (BOA). They assumed the same optical properties for dust from different source regions, which is different from the real conditions. The mineralogical composition and the Fe speciation in Icelandic dust are different from examples from northern African and Asian dust (Fig. 2, Table 2), leading to different 
spectral optical properties. Previous research investigated the absorption properties of volcanic sand deposited on snow, suggesting that the absorption properties of Icelandic dust from the Mýrdalssandur hotspot is similar to black carbon (Meinander et al., 2014; Peltoniemi et al., 2015). The spectral reflectance estimated for the pure volcanic sand was about 0.03 , which is very similar to a black body (0.0) (DagssonWaldhauserova, 2014; Peltoniemi et al., 2015). Zubko et al. (2019) measured the complex refractive index of milled volcanic sand from the same area. The imaginary part of the complex refractive index $(k)$, responsible for absorption, was $0.01(\lambda=647 \mathrm{~nm})$, which is around 1 order of magnitude higher than the average values for natural dust from the Sahel $(0.002, \lambda=660 \mathrm{~nm})$ and northern-Africa-Sahara and eastern Asia (0.001, $\lambda=660 \mathrm{~nm}$ ) (Di Biagio et al., 2019). In the shortwave spectrum, the $k$ values reported in literature for volcanic ash from Iceland range from around 0.0001 to 0.02 (Ball et al., 2015; Bukowiecki et al., 2011; Derimian et al., 2012; Hervo et al., 2012; Reed et al., 2017; Rocha-Lima et al., 2014; Schumann et al., 2011; Toledano et al., 2012; Vogel et al., 2017; Weinzierl et al., 2012), which makes it difficult to evaluate the absorption properties of volcanic dust.

Here we present a first estimate of the complex refractive index of Icelandic dust based on the mineral volume fractions determined in this study. For the scenario assuming all $\mathrm{FeD}$ as hematite, the calculations were repeated using different reference refractive indices for hematite and magnetite, and four scenarios were considered. The real part of the volume-average refractive index $(\tilde{n})$ has an average value of 1.60 at the selected wavelengths consistently in the different scenarios. The imaginary part of the volume-average index $(\tilde{k})$ calculated using the refractive index of magnetite from Huffman and Stapp (1973) is up to 1 order of magnitude higher than when using the data from Querry (1985) (Table 3). No significant variations were observed when applying the two different refractive indices for hematite (not shown). If using the data for magnetite from Querry (1985), $\tilde{k}$ showed little variation among the samples at the selected wavelengths, ranging from 0.001 to 0.003 . While using the data from Huffman and Stapp (1973), $\tilde{k}$ generally decreased from 470 to $660 \mathrm{~nm}$, and higher $\tilde{k}$ values were observed for D3, Maeli2 and H55 (0.006-0.01) compared to Land1 and MIR45 (0.004-0.006). Note that D3 has almost twice the magnetite content of Land1 and MIR45. Similar results are observed if assuming all $\mathrm{FeD}$ is goethite (Table 3). Overall, the estimated $\tilde{n}$ and $\tilde{k}$ values are within the range of $n$ and $k$ reported for volcanic ash. The $\tilde{k}$ value of the dust samples from the Mýrdalssandur hotspot is 0.002-0.004 at $\lambda=660 \mathrm{~nm}$, which is $2-5$ times lower than what observed in Zubko et al. (2019). The $\tilde{k}$ values estimated using the reference index of magnetite from Querry (1985) are comparable to the $k$ values reported in Di Biagio et al. (2019) for the Sahel, northern-Africa-Sahara and eastern Asia. Using the magnetite refractive index from Huffman and Stapp (1973), the estimated $\tilde{k}$ values rise up to 12 times higher than the $k$ of northern African and Asian dust from Di Biagio et al. (2019).

Our results indicate that magnetite can be a key factor contributing to the shortwave absorption of Icelandic dust, which is in agreement with the findings in Yoshida et al. (2016), who reported the presence of strongly light-absorbing minerals in Icelandic dust, which were identified as magnetite-like particles. Our analysis suggests that Icelandic dust may absorb solar radiation more than northern African and Asian natural dust, possibly leading to a stronger direct positive radiative effect in the Arctic than the estimates by Kylling et al. (2018).

There is large uncertainty in the estimated volume-average refractive index, which is related to complex refractive index of the amorphous glass and Fe oxides (Zhang et al., 2015). In addition, the method used here may overestimate absorption as the mineral phases are considered internally mixed in the dust samples (Formenti et al., 2014b). Direct measurements are thus necessary to evaluate the optical properties of Icelandic dust, which will be reported in a separate article.

\section{Conclusions}

In this study, we investigated the chemical composition and mineralogy of dust samples representative of five major dust hotspots in Iceland. Our results show that Icelandic dust is fundamentally different from low-latitude dust. Icelandic dust has a basaltic composition, and it is mainly composed of Ca-rich plagioclase, pyroxene and amorphous glass. The amorphous materials account for $8 \%$ (Hagavatn dust hotspot) to $60 \%-90 \%$ (Dyngjusandur, Landeyjarsandur, Mælifellssandur and Mýrdalssandur hotspots) of total dust mass. Mineralogical fractionation was not observed between dust samples and sediments. Icelandic dust has a high magnetite content and low hematite, goethite $(\mathrm{FeD})$ and amorphous $\mathrm{Fe}(\mathrm{FeA})$ contents. The initial Fe solubility (pH 4.7) is $0.08 \%-0.6 \%$. The low degree of weathering and low crystallinity are responsible for the high Fe solubility at low $\mathrm{pH}$ (up to $30 \%$ ).

Here we provide a comprehensive dataset including chemical composition, mineralogy, Fe speciation and Fe solubility of Icelandic dust, which can be fed to global models to estimate the flux of atmospheric soluble Fe to the sub-Arctic and Arctic oceans and to assess the radiative effect of Icelandic dust. Our analysis suggests that the shortwave absorption properties of Icelandic dust are determined by the high magnetite content, possibly leading to a stronger direct positive radiative effect in the Arctic than previous estimates. The original measurements of the spectral optical properties together with the size distribution conducted at CESAM will provide further insight into the absorption properties and long-range transport of Icelandic dust, which is necessary to estimate the radiative impact of Icelandic dust and its contribution to Arctic warming. 
Table 3. Estimated imaginary part of the volume-average refractive index of Icelandic dust ( $\mathrm{PM}_{10}$ fraction).

\begin{tabular}{|c|c|c|c|c|c|c|c|c|c|c|c|c|c|c|c|c|}
\hline \multirow{3}{*}{ Samples } & \multicolumn{8}{|c|}{ Assuming FeD is hematite } & \multicolumn{8}{|c|}{ Assuming FeD is goethite } \\
\hline & \multicolumn{2}{|c|}{$470 \mathrm{~nm}$} & \multicolumn{2}{|c|}{$520 \mathrm{~nm}$} & \multicolumn{2}{|c|}{$590 \mathrm{~nm}$} & \multicolumn{2}{|c|}{$660 \mathrm{~nm}$} & \multicolumn{2}{|c|}{$470 \mathrm{~nm}$} & \multicolumn{2}{|c|}{$520 \mathrm{~nm}$} & \multicolumn{2}{|c|}{$590 \mathrm{~nm}$} & \multicolumn{2}{|c|}{$660 \mathrm{~nm}$} \\
\hline & $\tilde{k} 1$ & $\tilde{k} 2$ & $\tilde{k} 1$ & $\tilde{k} 2$ & $\tilde{k} 1$ & $\tilde{k} 2$ & $\tilde{k} 1$ & $\tilde{k} 2$ & $\tilde{k} 1$ & $\tilde{k} 2$ & $\tilde{k} 1$ & $\tilde{k} 2$ & $\tilde{k} 1$ & $\tilde{k} 2$ & $\tilde{k} 1$ & $\tilde{k} 2$ \\
\hline H55 & 0.009 & 0.002 & 0.008 & 0.002 & 0.007 & 0.002 & 0.006 & 0.002 & 0.009 & 0.001 & 0.008 & 0.002 & 0.007 & 0.002 & 0.007 & 0.002 \\
\hline Land1 & 0.006 & 0.002 & 0.005 & 0.002 & 0.004 & 0.001 & 0.004 & 0.001 & 0.005 & 0.001 & 0.005 & 0.002 & 0.005 & 0.002 & 0.004 & 0.002 \\
\hline Maeli2 & 0.011 & 0.003 & 0.009 & 0.002 & 0.008 & 0.002 & 0.007 & 0.002 & 0.010 & 0.002 & 0.009 & 0.003 & 0.008 & 0.003 & 0.008 & 0.003 \\
\hline
\end{tabular}

Note that the $\tilde{k} 1$ and $\tilde{k} 2$ values are calculated using two different complex refractive indices for magnetite from Huffman and Stapp (1973) and Querry (1985), respectively. If assuming FeD is purely hematite, the data shown in the table are calculated using the data from Longtin et al. (1988).

Data availability. The element oxide mass percentages, the chemical index of alteration and relevant element ratios for the different Icelandic dust samples ( $\mathrm{PM}_{10}$ fraction) are reported in Table 1. The mineralogical composition of $\mathrm{PM}_{10}$ samples and parent sediments is provided in Table 2. The Fe speciation and solubility of the $\mathrm{PM}_{10}$ fractions are provided in Table $\mathrm{S} 3$ in the Supplement. Data are available at https://doi.org/10.25500/edata.bham.00000565 (Baldo, 2020).

Supplement. The supplement related to this article is available online at: https://doi.org/10.5194/acp-20-13521-2020-supplement.

Author contributions. CB, ZS, CDB, PF and JFD designed the experiments and discussed the results. ZS supervised the experimental and data analyses. CB performed the experiments at CESAM and the data analysis with contributions from ZS, ARM, CDB, PF, $\mathrm{MC}, \mathrm{EP}$ and JFD. The soil samples used for the experiments were collected by OA and PDW. CB and SN performed the XRD measurements. SC and PF performed the XRF measurements. CB, ZS and KI performed the XANES measurements. CB performed the Fe extractions and solubility measurements. CB and ZS prepared the article with contributions from all co-authors.

Competing interests. The authors declare that they have no conflict of interest.

Special issue statement. This article is part of the special issue "Simulation chambers as tools in atmospheric research (AMT/ACP/GMD inter-journal SI)". It is not associated with a conference.

Acknowledgements. Clarissa Baldo is funded by the Natural Environment Research Council (NERC) CENTA studentship (grant no. NE/L002493/1). This paper is partly funded by the NERC highlight topic project (NE/S00579X/1). This project has received funding from the European Union's Horizon 2020 research and innovation programme through the EUROCHAMP-2020 Infrastructure Activity under grant agreement No 730997. Part of this work was sup- ported by the COST Action inDust (CA16202) supported by COST (European Cooperation in Science and Technology). This work was carried out with the support of the Icelandic Research Fund (Rannís) grant no. 207057-051. We acknowledge Diamond Light Source for time on Beamline/Lab I18 under the Proposals: SP22244-1; SP12760-1; SP10327-1. The authors gratefully acknowledge Gautier Landrot (SAMBAA SOLEIL), who provided his expertise for the analysis of the XANES spectra and results. Thanks also to Giannantonio Cibin (Diamond Light Source), who provided the magnetite standard for the XANES measurements.

Financial support. This research has been supported by the Natural Environment Research Council (grant no. NE/L002493/1), the Natural Environment Research Council (grant no. NE/S00579X/1), the European Commission, Horizon 2020 (grant no. EUROCHAMP2020 (730997)), the European Cooperation in Science and Technology (grant no. CA16202) and the Icelandic Research Fund (Rannís) (grant no. 207057-051).

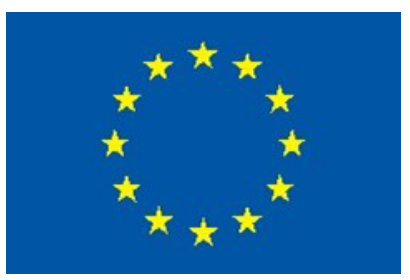

Review statement. This paper was edited by Allan Bertram and reviewed by Konrad Kandler and one anonymous referee.

\section{References}

Achterberg, E. P., Moore, C. M., Henson, S. A., Steigenberger, S., Stohl, A., Eckhardt, S., Avendano, L. C., Cassidy, M., Hembury, D., Klar, J. K., Lucas, M. I., Macey, A. I., Marsay, C. M., and Ryan-Keogh, T. J.: Natural iron fertilization by the Eyjafjallajökull volcanic eruption, Geophys. Res. Lett., 40, 921-926, https://doi.org/10.1002/grl.50221, 2013.

Arimoto, R.: Eolian dust and climate: relationships to sources, tropospheric chemistry, transport and deposition, Earth-Sci. 
Rev., 54, 29-42, https://doi.org/10.1016/s0012-8252(01)00040$\mathrm{x}, 2001$.

Arnalds, O.: Dust sources and deposition of aeolian materials in Iceland, Iceland. Agr. Sci., 23, 3-21, 2010.

Arnalds, O.: The soils of Iceland, World Soils Book Series, Springer, Dordrecht, ISBN 978-94-017-9620-0, 2015.

Arnalds, O., Gisladottir, F. O., and Sigurjonsson, H.: Sandy deserts of Iceland: an overview, J. Arid Environ., 47, 359-371, https://doi.org/10.1006/jare.2000.0680, 2001.

Arnalds, O., Olafsson, H., and Dagsson-Waldhauserova, P.: Quantification of iron-rich volcanogenic dust emissions and deposition over the ocean from Icelandic dust sources, Biogeosciences, 11, 6623-6632, https://doi.org/10.5194/bg-11-6623-2014, 2014.

Arnalds, O., Dagsson-Waldhauserova, P., and Olafsson, H.: The Icelandic volcanic aeolian environment: Processes and impacts - A review, Aeolian Res., 20, 176-195, https://doi.org/10.1016/j.aeolia.2016.01.004, 2016.

Atkinson, J. D., Murray, B. J., Woodhouse, M. T., Whale, T. F., Baustian, K. J., Carslaw, K. S., Dobbie, S., O'Sullivan, D., and Malkin, T. L.: The importance of feldspar for ice nucleation by mineral dust in mixed-phase clouds, Nature, 498, 355-358, https://doi.org/10.1038/nature12278, 2013.

Avila, A., QueraltMitjans, I., and Alarcon, M.: Mineralogical composition of African dust delivered by red rains over northeastern Spain, J. Geophys. Res.-Atmos., 102, 21977-21996, https://doi.org/10.1029/97jd00485, 1997.

Ayris, P. and Delmelle, P.: Volcanic and atmospheric controls on ash iron solubility: A review, Phys. Chem. Earth, 45-46, 103-112, https://doi.org/10.1016/j.pce.2011.04.013, 2012.

Baddock, M. C., Mockford, T., Bullard, J. E., and Thorsteinsson, T.: Pathways of high-latitude dust in the North Atlantic, Earth Planet. Sc. Lett., 459, 170-182, https://doi.org/10.1016/j.epsl.2016.11.034, 2017.

Baker, A. R., Jickells, T. D., Witt, M., and Linge, K. L.: Trends in the solubility of iron, aluminium, manganese and phosphorus in aerosol collected over the Atlantic Ocean, Mar. Chem., 98, 4358, https://doi.org/10.1016/j.marchem.2005.06.004, 2006.

Baldo, C.: Research data supporting "Distinct chemical and mineralogical composition of Icelandic dust compared to northern African and Asian dust", https://doi.org/10.25500/edata.bham.00000565, 2020.

Ball, J. G. C., Reed, B. E., Grainger, R. G., Peters, D. M., Mather, T. A., and Pyle, D. M.: Measurements of the complex refractive index of volcanic ash at 450, 546.7, and $650 \mathrm{~nm}$, J. Geophys. Res.Atmos., 120, 7747-7757, https://doi.org/10.1002/2015jd023521, 2015.

Baratoux, D., Mangold, N., Arnalds, O., Bardintzeff, J. M., Platevoët, B., Grégoire, M., and Pinet, P.: Volcanic sands of Iceland Diverse origins of aeolian sand deposits revealed at Dyngjusandur and Lambahraun, Earth Surf. Proc. Land., 36, 1789-1808, https://doi.org/10.1002/esp.2201, 2011.

Bedidi, A. and Cervelle, B.: Light scattering by spherical particles with hematite and goethitelike optical properties: effect of water impregnation, J. Geophys. Res.-Sol. Ea., 98, 11941-11952, https://doi.org/10.1029/93JB00188, 1993.

Björnsson, H. and Palsson, F.: Icelandic glaciers, Jokull, 58, 365386, 2008

Boucher, O., Randall, D., Artaxo, P., Bretherton, C., Feingold, G., Forster, P., Kerminen, V.-M., Kondo, Y., Liao, H., Lohmann, U.,
Rasch, P., Satheesh, S., Sherwood, S., Stevens, B., and Zhang, X.-Y.: Clouds and aerosols, in: Climate change 2013: the physical science basis. Contribution of Working Group I to the Fifth Assessment Report of the Intergovernmental Panel on Climate Change, edited by: Stocker, T. F., Qin, D., Plattner, G.-K., Tignor, M., Allen, S. K., Doschung, J., Nauels, A., Xia, Y., Bex, V., and Midgley, P. M., Cambridge University Press, United Kingdom and New York USA, 571-657, 2013.

Bukowiecki, N., Zieger, P., Weingartner, E., Jurányi, Z., Gysel, M., Neininger, B., Schneider, B., Hueglin, C., Ulrich, A., Wichser, A., Henne, S., Brunner, D., Kaegi, R., Schwikowski, M., Tobler, L., Wienhold, F. G., Engel, I., Buchmann, B., Peter, T., and Baltensperger, U.: Ground-based and airborne in-situ measurements of the Eyjafjallajökull volcanic aerosol plume in Switzerland in spring 2010, Atmos. Chem. Phys., 11, 10011-10030, https://doi.org/10.5194/acp-11-10011-2011, 2011.

Bullard, J. E., Baddock, M., Bradwell, T., Crusius, J., Darlington, E., Gaiero, D., Gasso, S., Gisladottir, G., Hodgkins, R., McCulloch, R., McKenna-Neuman, C., Mockford, T., Stewart, H., and Thorsteinsson, T.: High-latitude dust in the Earth system, Rev. Geophys., 54, 447-485, https://doi.org/10.1002/2016rg000518, 2016.

Caponi, L., Formenti, P., Massabó, D., Di Biagio, C., Cazaunau, M., Pangui, E., Chevaillier, S., Landrot, G., Andreae, M. O., Kandler, K., Piketh, S., Saeed, T., Seibert, D., Williams, E., Balkanski, Y., Prati, P., and Doussin, J.-F.: Spectral- and size-resolved mass absorption efficiency of mineral dust aerosols in the shortwave spectrum: a simulation chamber study, Atmos. Chem. Phys., 17, 7175-7191, https://doi.org/10.5194/acp-17-7175-2017, 2017.

Carslaw, K. S., Boucher, O., Spracklen, D. V., Mann, G. W., Rae, J. G. L., Woodward, S., and Kulmala, M.: A review of natural aerosol interactions and feedbacks within the Earth system, Atmos. Chem. Phys., 10, 1701-1737, https://doi.org/10.5194/acp10-1701-2010, 2010.

Chen, H., Nanayakkara, C. E., and Grassian, V. H.: Titanium dioxide photocatalysis in atmospheric chemistry, Chem. Rev., 112, 5919-5948, https://doi.org/10.1021/cr3002092, 2012.

Choobari, O. A., Zawar-Reza, P., and Sturman, A.: The global distribution of mineral dust and its impacts on the climate system: A review, Atmos. Res., 138, 152-165, https://doi.org/10.1016/j.atmosres.2013.11.007, 2014.

Claquin, T., Schulz, M., and Balkanski, Y. J.: Modeling the mineralogy of atmospheric dust sources, J. Geophys. Res.-Atmos., 104, 22243-22256, https://doi.org/10.1029/1999jd900416, 1999.

Cornell, R. M. and Schwertmann, U.: The Iron Oxides: Structure, Properties, Reactions, Occurrence and Uses, Wiley-VCH, New York, ISBN 3-527-30274-3, 2003.

Crusius, J., Schroth, A. W., Gasso, S., Moy, C. M., Levy, R. C., and Gatica, M.: Glacial flour dust storms in the Gulf of Alaska: Hydrologic and meteorological controls and their importance as a source of bioavailable iron, Geophys. Res. Lett., 38, L06602, https://doi.org/10.1029/2010gl046573, 2011.

Cwiertny, D. M., Baltrusaitis, J., Hunter, G. J., Laskin, A., Scherer, M. M., and Grassian, V. H.: Characterization and acid-mobilization study of iron-containing mineral dust source materials, J. Geophys. Res.-Atmos., 113, D0520, https://doi.org/10.1029/2007jd009332, 2008.

Dagsson-Waldhauserova, P.: Variability, origin and physical characteristics of dust aerosol in Iceland (PhD dissertation), Faculty of 
Physical Sciences Agricultural University of Iceland, Reykjavik, 163 pp., 2014.

Dagsson-Waldhauserova, P., Arnalds, O., and Olafsson, H.: Longterm variability of dust events in Iceland (1949-2011), Atmos. Chem. Phys., 14, 13411-13422, https://doi.org/10.5194/acp-1413411-2014, 2014a.

Dagsson-Waldhauserova, P., Arnalds, O., Olafsson, H., Skrabalova, L., Sigurdardottir, G. M., Branis, M., Hladil, J., Skala, R., Navratil, T., Chadimova, L., Menar, S. V. O., Thorsteinsson, T., Carlsen, H. K., and Jonsdottir, I.: Physical properties of suspended dust during moist and low wind conditions in Iceland, Iceland. Agr. Sci., 27, 25-39, 2014b.

Dagsson-Waldhauserova, P., Arnalds, O., Olafsson, H., Hladil, J., Skala, R., Navratil, T., Chadimova, L., and Meinander, O.: Snow-Dust Storm: Unique case study from Iceland, March 6-7, 2013, Aeolian Res., 16, 69-74, https://doi.org/10.1016/j.aeolia.2014.11.001, 2015.

Degen, T., Sadki, M., Bron, E., König, U., and Nénert, G.: The highscore suite, Powder Diffr., 29, S13-S18, https://doi.org/10.1017/S0885715614000840, 2014.

Derimian, Y., Karnieli, A., Kaufman, Y. J., Andreae, M. O., Andreae, T. W., Dubovik, O., Maenhaut, W., and Koren, I.: The role of iron and black carbon in aerosol light absorption, Atmos. Chem. Phys., 8, 3623-3637, https://doi.org/10.5194/acp-8-36232008, 2008.

Derimian, Y., Dubovik, O., Tanre, D., Goloub, P., Lapyonok, T., and Mortier, A.: Optical properties and radiative forcing of the Eyjafjallajökull volcanic ash layer observed over Lille, France, in 2010, J. Geophys. Res.-Atmos., 117, D00U25, https://doi.org/10.1029/2011jd016815, 2012.

Desboeufs, K. V., Sofikitis, A., Losno, R., Colin, J. L., and Ausset, P.: Dissolution and solubility of trace metals from natural and anthropogenic aerosol particulate matter, Chemosphere, 58, 195203, https://doi.org/10.1016/j.chemosphere.2004.02.025, 2005.

Di Biagio, C., Formenti, P., Balkanski, Y., Caponi, L., Cazaunau, M., Pangui, E., Journet, E., Nowak, S., Caquineau, S., Andreae, M. O., Kandler, K., Saeed, T., Piketh, S., Seibert, D., Williams, E., and Doussin, J.-F.: Global scale variability of the mineral dust long-wave refractive index: a new dataset of in situ measurements for climate modeling and remote sensing, Atmos. Chem. Phys., 17, 1901-1929, https://doi.org/10.5194/acp17-1901-2017, 2017.

Di Biagio, C., Formenti, P., Balkanski, Y., Caponi, L., Cazaunau, M., Pangui, E., Journet, E., Nowak, S., Andreae, M. O., Kandler, K., Saeed, T., Piketh, S., Seibert, D., Williams, E., and Doussin, J.-F.: Complex refractive indices and single-scattering albedo of global dust aerosols in the shortwave spectrum and relationship to size and iron content, Atmos. Chem. Phys., 19, 15503-15531, https://doi.org/10.5194/acp-19-15503-2019, 2019.

Dordevic, D., Tosic, I., Sakan, S., Petrovic, S., DuricicMilankovic, J., Finger, D. C., and Dagsson-Waldhauserova, P.: Can Volcanic Dust Suspended From Surface Soil and Deserts of Iceland Be Transferred to Central Balkan Similarly to African Dust (Sahara)?, Front. Earth Sci., 7, UNSP 142, https://doi.org/10.3389/feart.2019.00142, 2019.

Dragosics, M., Meinander, O., Jónsdóttír, T., Dürig, T., De Leeuw, G., Pálsson, F., Dagsson-Waldhauserová, P., and Thorsteinsson, T.: Insulation effects of Icelandic dust and volcanic ash on snow and ice, Arab. J. Geosci., 9, 126, https://doi.org/10.1007/s12517015-2224-6, 2016.

Duggen, S., Olgun, N., Croot, P., Hoffmann, L., Dietze, H., Delmelle, P., and Teschner, C.: The role of airborne volcanic ash for the surface ocean biogeochemical iron-cycle: a review, Biogeosciences, 7, 827-844, https://doi.org/10.5194/bg-7-8272010, 2010.

Dumont, M., Brun, E., Picard, G., Michou, M., Libois, Q., Petit, J. R., Geyer, M., Morin, S., and Josse, B.: Contribution of light-absorbing impurities in snow to Greenland's darkening since 2009, Nat. Geosci., 7, 509-512, https://doi.org/10.1038/ngeo2180, 2014.

Engelbrecht, J. P., Moosmüller, H., Pincock, S., Jayanty, R. K. M., Lersch, T., and Casuccio, G.: Technical note: Mineralogical, chemical, morphological, and optical interrelationships of mineral dust re-suspensions, Atmos. Chem. Phys., 16, 10809-10830, https://doi.org/10.5194/acp-16-10809-2016, 2016.

Formenti, P., Nava, S., Prati, P., Chevaillier, S., Klaver, A., Lafon, S., Mazzei, F., Calzolai, G., and Chiari, M.: Selfattenuation artifacts and correction factors of light element measurements by X-ray analysis: Implication for mineral dust composition studies, J. Geophys. Res.-Atmos., 115, D01203, https://doi.org/10.1029/2009JD012701, 2010.

Formenti, P., Schütz, L., Balkanski, Y., Desboeufs, K., Ebert, M., Kandler, K., Petzold, A., Scheuvens, D., Weinbruch, S., and Zhang, D.: Recent progress in understanding physical and chemical properties of African and Asian mineral dust, Atmos. Chem. Phys., 11, 8231-8256, https://doi.org/10.5194/acp11-8231-2011, 2011.

Formenti, P., Caquineau, S., Chevaillier, S., Klaver, A., Desboeufs, K., Rajot, J. L., Belin, S., and Briois, V.: Dominance of goethite over hematite in iron oxides of mineral dust from Western Africa: Quantitative partitioning by X-ray absorption spectroscopy, J. Geophys. Res.-Atmos., 119, 12740-12754, https://doi.org/10.1002/2014jd021668, 2014a.

Formenti, P., Caquineau, S., Desboeufs, K., Klaver, A., Chevaillier, S., Journet, E., and Rajot, J. L.: Mapping the physicochemical properties of mineral dust in western Africa: mineralogical composition, Atmos. Chem. Phys., 14, 10663-10686, https://doi.org/10.5194/acp-14-10663-2014, 2014b.

Frogner, P., Gislason, S. R., and Oskarsson, N.: Fertilizing potential of volcanic ash in ocean surface water, Geology, 29, 487-490, https://doi.org/10.1130/00917613(2001)029<0487:Fpovai>2.0.Co;2, 2001.

Fu, H., Cwiertny, D. M., Carmichael, G. R., Scherer, M. M., and Grassian, V. H.: Photoreductive dissolution of Fe-containing mineral dust particles in acidic media, J. Geophys. Res., 115, D11304, https://doi.org/10.1029/2009jd012702, 2010.

Groot Zwaaftink, C. D., Grythe, H., Skov, H., and Stohl, A.: Substantial contribution of northern high-latitude sources to mineral dust in the Arctic, J. Geophys. Res.-Atmos., 121, 13678-13697, https://doi.org/10.1002/2016jd025482, 2016.

Groot Zwaaftink, C. D., Arnalds, Ó., Dagsson-Waldhauserova, P., Eckhardt, S., Prospero, J. M., and Stohl, A.: Temporal and spatial variability of Icelandic dust emissions and atmospheric transport, Atmos. Chem. Phys., 17, 10865-10878, https://doi.org/10.5194/acp-17-10865-2017, 2017.

Haywood, J., Francis, P., Osborne, S., Glew, M., Loeb, N., Highwood, E., Tanre, D., Myhre, G., Formenti, P., and Hirst, 
E.: Radiative properties and direct radiative effect of Saharan dust measured by the C-130 aircraft during SHADE: 1. Solar spectrum, J. Geophys. Res.-Atmos., 108, 8577, https://doi.org/10.1029/2002jd002687, 2003.

Hervo, M., Quennehen, B., Kristiansen, N. I., Boulon, J., Stohl, A., Fréville, P., Pichon, J.-M., Picard, D., Labazuy, P., Gouhier, M., Roger, J.-C., Colomb, A., Schwarzenboeck, A., and Sellegri, K.: Physical and optical properties of 2010 Eyjafjallajökull volcanic eruption aerosol: ground-based, Lidar and airborne measurements in France, Atmos. Chem. Phys., 12, 17211736, https://doi.org/10.5194/acp-12-1721-2012, 2012.

Huffman, D. R. and Stapp, J. L.: Optical measurements on solids of possible interstellar importance, in: Interstellar dust and related topics, Springer, 297-301, 1973.

Jakobsson, S. P. and Gudmundsson, M. T.: Subglacial and intraglacial volcanic formations in Iceland, Jokull, 58, 179-196, 2008.

Jensen, E. H., Egilson, D., Pagneux, E., Björnsson, B. B., Zóphóníasson, S., Snorrason, S. P., Jónsdóttir, I., Prastarson, R. H., igurðsson, O. S., and Roberts, M. J.: Hættumat vegna jökulhlaupa í Skaftá [Danger of Skafta jokulhlaup], Icelandic Meteorological Office Report VÍ 2018-0xx, available at: http://www.vedur.is/media/EplicanC3A1mskeiC3B0/ 2018_skaftarhlaup_soguleg_gogn_lokadrog_rs.pdf (last access: 4 January 2020), 2018.

Jeong, G. Y.: Bulk and single-particle mineralogy of Asian dust and a comparison with its source soils, J. Geophys. Res.-Atmos., 113, D02208, https://doi.org/10.1029/2007jd008606, 2008.

Jeong, G. Y., Park, M. Y., Kandler, K., Nousiainen, T., and Kemppinen, O.: Mineralogical properties and internal structures of individual fine particles of Saharan dust, Atmos. Chem. Phys., 16, 12397-12410, https://doi.org/10.5194/acp-16-12397-2016, 2016.

Jia, J., Wang, Y. J., Xia, D. S., Lu, H., and Gao, F. Y.: Dust Sources of Last Glacial Chinese Loess Based on the Iron Mineralogy of Fractionated Source Samples, Geophys. Res. Lett., 46, 21032110, https://doi.org/10.1029/2018g1080909, 2019.

Jickells, T. and Moore, C. M.: The importance of Atmospheric Deposition for Ocean Productivity, Annu. Rev. Ecol. Evol. S., 46, 481-501, https://doi.org/10.1146/annurev-ecolsys-112414054118, 2015.

Jickells, T. D., An, Z. S., Andersen, K. K., Baker, A. R., Bergametti, G., Brooks, N., Cao, J. J., Boyd, P. W., Duce, R. A., Hunter, K. A., Kawahata, H., Kubilay, N., laRoche, J., Liss, P. S., Mahowald, N., Prospero, J. M., Ridgwell, A. J., Tegen, I., and Torres, R.: Global iron connections between desert dust, ocean biogeochemistry, and climate, Science, 308, 67-71, https://doi.org/10.1126/science.1105959, 2005.

Jones, M. T. and Gislason, S. R.: Rapid releases of metal salts and nutrients following the deposition of volcanic ash into aqueous environments, Geochim. Cosmochim. Ac., 72, 3661-3680, https://doi.org/10.1016/j.gca.2008.05.030, 2008.

Journet, E., Desboeufs, K. V., Caquineau, S., and Colin, J. L.: Mineralogy as a critical factor of dust iron solubility, Geophys. Res. Lett., 35, L07805, https://doi.org/10.1029/2007g1031589, 2008.

Journet, E., Balkanski, Y., and Harrison, S. P.: A new data set of soil mineralogy for dust-cycle modeling, Atmos. Chem. Phys., 14, 3801-3816, https://doi.org/10.5194/acp-14-3801-2014, 2014.
Kanakidou, M., Myriokefalitakis, S., and Tsigaridis, K.: Aerosols in atmospheric chemistry and biogeochemical cycles of nutrients, Environ. Res. Lett., 13, blackboxPlease provide article number or page range. https://doi.org/10.1088/1748-9326/aabcdb, 2018.

Kandler, K., Schutz, L., Deutscher, C., Ebert, M., Hofmann, H., Jackel, S., Jaenicke, R., Knippertz, P., Lieke, K., Massling, A., Petzold, A., Schladitz, A., Weinzierl, B., Wiedensohler, A., Zorn, S., and Weinbruch, S.: Size distribution, mass concentration, chemical and mineralogical composition and derived optical parameters of the boundary layer aerosol at Tinfou, Morocco, during SAMUM 2006, Tellus B, 61, 32-50, https://doi.org/10.1111/j.1600-0889.2008.00385.x, 2009.

Kylling, A., Zwaaftink, C. D. G., and Stohl, A.: Mineral Dust Instantaneous Radiative Forcing in the Arctic, Geophys. Res. Lett., 45, 4290-4298, https://doi.org/10.1029/2018g1077346, 2018.

Lafon, S., Sokolik, I. N., Rajot, J. L., Caquineau, S., and Gaudichet, A.: Characterization of iron oxides in mineral dust aerosols: Implications for light absorption, J. Geophys. Res.-Atmos., 111, D21207, https://doi.org/10.1029/2005jd007016, 2006.

Lazaro, F. J., Gutierrez, L., Barron, V., and Gelado, M. D.: The speciation of iron in desert dust collected in Gran Canaria (Canary Islands): Combined chemical, magnetic and optical analysis, Atmos. Environ., 42, 8987-8996, https://doi.org/10.1016/j.atmosenv.2008.09.035, 2008.

Longtin, D. R., Shettle, E. P., Hummel, J. R., and Pryce, J. D.: A wind dependent desert aerosol model: Radiative properties, AFGLTR-88-0112, Air Force Geophysics Laboratory, Hanscom AFB, MA, 1988.

Lu, W. Y., Zhao, W. C., Balsam, W., Lu, H., Liu, P., Lu, Z. L., and Ji, J. F.: Iron Mineralogy and Speciation in Clay-Sized Fractions of Chinese Desert Sediments, J. Geophys. Res.-Atmos., 122, 13458-13471, https://doi.org/10.1002/2017jd027733, 2017.

Lutterotti, L., Ceccato, R., Dal Maschio, R., and Pagani, E.: Quantitative analysis of silicate glass in ceramic materials by the Rietveld method, Mater. Sci. Forum, 278, 87-92, 1998.

Lutterotti, L., Matthies, S., and Wenk, H.: MAUD: a friendly Java program for material analysis using diffraction, IUCr: Newsletter of the CPD, 21, 1999.

Maher, B. A., Mutch, T. J., and Cunningham, D.: Magnetic and geochemical characteristics of Gobi Desert surface sediments: Implications for provenance of the Chinese Loess Plateau, Geology, 37, 279-282, https://doi.org/10.1130/g25293a.1, 2009.

Maher, B. A., Prospero, J. M., Mackie, D., Gaiero, D., Hesse, P. P., and Balkanski, Y.: Global connections between aeolian dust, climate and ocean biogeochemistry at the present day and at the last glacial maximum, Earth-Sci. Rev., 99, 61-97, https://doi.org/10.1016/j.earscirev.2009.12.001, 2010.

Mahowald, N. M., Kloster, S., Engelstaedter, S., Moore, J. K., Mukhopadhyay, S., McConnell, J. R., Albani, S., Doney, S. C., Bhattacharya, A., Curran, M. A. J., Flanner, M. G., Hoffman, F. M., Lawrence, D. M., Lindsay, K., Mayewski, P. A., Neff, J., Rothenberg, D., Thomas, E., Thornton, P. E., and Zender, C. S.: Observed 20th century desert dust variability: impact on climate and biogeochemistry, Atmos. Chem. Phys., 10, 10875-10893, https://doi.org/10.5194/acp-10-10875-2010, 2010.

Maters, E. C., Delmelle, P., and Gunnlaugsson, H. P.: Controls on iron mobilisation from volcanic ash at low $\mathrm{pH}$ : Insights from dissolution experiments and Mossbauer spectroscopy, Chem. Geol., 
449, 73-81, https://doi.org/10.1016/j.chemgeo.2016.11.036, 2017.

Meinander, O., Kontu, A., Virkkula, A., Arola, A., Backman, L., Dagsson-Waldhauserová, P., Järvinen, O., Manninen, T., Svensson, J., de Leeuw, G., and Leppäranta, M.: Brief communication: Light-absorbing impurities can reduce the density of melting snow, The Cryosphere, 8, 991-995, https://doi.org/10.5194/tc-8991-2014, 2014.

Meskhidze, N., Johnson, M. S., Hurley, D., and Dawson, K.: Influence of measurement uncertainties on fractional solubility of iron in mineral aerosols over the oceans, Aeolian Res., 22, 85 92, https://doi.org/10.1016/j.aeolia.2016.07.002, 2016.

Möller, R., Möller, M., Kukla, P. A., and Schneider, C.: Impact of supraglacial deposits of tephra from Grímsvötn volcano, Iceland, on glacier ablation, J. Glaciol., 62, 933-943, https://doi.org/10.1017/jog.2016.82, 2016.

Möller, R., Möller, M., Kukla, P. A., and Schneider, C.: Modulation of glacier ablation by tephra coverage from Eyjafjallajökull and Grímsvötn volcanoes, Iceland: an automated field experiment, Earth Syst. Sci. Data, 10, 53-60, https://doi.org/10.5194/essd-1053-2018, 2018.

Moore, C. M., Mills, M. M., Milne, A., Langlois, R., Achterberg, E. P., Lochte, K., Geider, R. J., and La Roche, J.: Iron limits primary productivity during spring bloom development in the central North Atlantic, Glob. Change Biol., 12, 626-634, https://doi.org/10.1111/j.1365-2486.2006.01122.x, 2006.

Moosmuller, H., Engelbrecht, J. P., Skiba, M., Frey, G., Chakrabarty, R. K., and Arnott, W. P.: Single scattering albedo of fine mineral dust aerosols controlled by iron concentration, J. Geophys. Res.-Atmos., 117, D11210, https://doi.org/10.1029/2011jd016909, 2012.

Moroni, B., Arnalds, O., Dagsson-Waldhauserova, P., Crocchianti, S., Vivani, R., and Cappelletti, D.: Mineralogical and Chemical Records of Icelandic Dust Sources Upon Ny-angstrom lesund (Svalbard Islands), Front. Earth Sci., 6, UNSP 187, https://doi.org/10.3389/feart.2018.00187, 2018.

Moskowitz, B. M., Reynolds, R. L., Goldstein, H. L., Berquo, T. S., Kokaly, R. F., and Bristow, C. S.: Iron oxide minerals in dust-source sediments from the Bodele Depression, Chad: Implications for radiative properties and Fe bioavailability of dust plumes from the Sahara, Aeolian Res., 22, 93-106, https://doi.org/10.1016/j.aeolia.2016.07.001, 2016.

Myriokefalitakis, S., Ito, A., Kanakidou, M., Nenes, A., Krol, M. C., Mahowald, N. M., Scanza, R. A., Hamilton, D. S., Johnson, M. S., Meskhidze, N., Kok, J. F., Guieu, C., Baker, A. R., Jickells, T. D., Sarin, M. M., Bikkina, S., Shelley, R., Bowie, A., Perron, M. M. G., and Duce, R. A.: Reviews and syntheses: the GESAMP atmospheric iron deposition model intercomparison study, Biogeosciences, 15, 6659-6684, https://doi.org/10.5194/bg-15-66592018, 2018.

Nesbitt, H. W. and Young, G. M.: Prediction of some weathering trends of plutonic and volcanic-rocks based on thermodynamic and kinetic considerations, Geochim. Cosmochim. Ac., 48, 1523-1534, https://doi.org/10.1016/0016-7037(84)90408-3, 1984.

Nielsdottir, M. C., Moore, C. M., Sanders, R., Hinz, D. J., and Achterberg, E. P.: Iron limitation of the postbloom phytoplankton communities in the Iceland Basin, Global Biogeochem. Cy., 23, GB3001, https://doi.org/10.1029/2008gb003410, 2009.
Oakes, M., Ingall, E. D., Lai, B., Shafer, M. M., Hays, M. D., Liu, Z. G., Russell, A. G., and Weber, R. J.: Iron Solubility Related to Particle Sulfur Content in Source Emission and Ambient Fine Particles, Environ. Sci. Technol., 46, 6637-6644, https://doi.org/10.1021/es300701c, 2012.

Oladottir, B. A., Sigmarsson, O., Larsen, G., and Thordarson, T.: Katla volcano, Iceland: magma composition, dynamics and eruption frequency as recorded by Holocene tephra layers, B. Volcanol., 70, 475-493, https://doi.org/10.1007/s00445-007-0150$5,2008$.

Olgun, N., Duggen, S., Croot, P. L., Delmelle, P., Dietze, H., Schacht, U., Oskarsson, N., Siebe, C., Auer, A., and Garbe-Schonberg, D.: Surface ocean iron fertilization: The role of airborne volcanic ash from subduction zone and hot spot volcanoes and related iron fluxes into the Pacific Ocean, Global Biogeochem. Cy., 25, GB4001, https://doi.org/10.1029/2009gb003761, 2011.

Oskarsson, N.: The interaction between volcanic gases and tephra fluorine adhering to tephra of the 1970 Hekla eruption, J. Volcanol. Geoth. Res., 8, 251-266, https://doi.org/10.1016/03770273(80)90107-9, 1980.

Paramonov, M., David, R. O., Kretzschmar, R., and Kanji, Z. A.: A laboratory investigation of the ice nucleation efficiency of three types of mineral and soil dust, Atmos. Chem. Phys., 18, 1651516536, https://doi.org/10.5194/acp-18-16515-2018, 2018.

Peltoniemi, J. I., Gritsevich, M., Hakala, T., DagssonWaldhauserová, P., Arnalds, Ó., Anttila, K., Hannula, H.-R., Kivekäs, N., Lihavainen, H., Meinander, O., Svensson, J., Virkkula, A., and de Leeuw, G.: Soot on Snow experiment: bidirectional reflectance factor measurements of contaminated snow, The Cryosphere, 9, 2323-2337, https://doi.org/10.5194/tc9-2323-2015, 2015.

Poulton, S. W. and Canfield, D. E.: Development of a sequential extraction procedure for iron: implications for iron partitioning in continentally derived particulates, Chem. Geol., 214, 209-221, https://doi.org/10.1016/j.chemgeo.2004.09.003, 2005.

Price, J. R. and Velbel, M. A.: Chemical weathering indices applied to weathering profiles developed on heterogeneous felsic metamorphic parent rocks, Chem. Geol., 202, 397-416, https://doi.org/10.1016/j.chemgeo.2002.11.001, 2003.

Prospero, J. M., Bullard, J. E., and Hodgkins, R.: HighLatitude Dust Over the North Atlantic: Inputs from Icelandic Proglacial Dust Storms, Science, 335, 1078-1082, https://doi.org/10.1126/science.1217447, 2012.

Qian, Y., Yasunari, T. J., Doherty, S. J., Flanner, M. G., Lau, W. K. M., Ming, J., Wang, H. L., Wang, M., Warren, S. G., and Zhang, R. D.: Light-absorbing Particles in Snow and Ice: Measurement and Modeling of Climatic and Hydrological impact, Adv. Atmos. Sci., 32, 64-91, https://doi.org/10.1007/s00376-014-0010$0,2015$.

Querry, M. R.: Magnetite, Refractive index database, available at: https://refractiveindex.info/?shelf=main\&book=Fe3O4\& (last access: 2 January 2020), 1985.

Raiswell, R., Benning, L. G., Tranter, M., and Tulaczyk, S.: Bioavailable iron in the Southern Ocean: the significance of the iceberg conveyor belt, Geochem. T., 9, 7, https://doi.org/10.1186/1467-4866-9-7, 2008.

Raiswell, R., Hawkings, J. R., Benning, L. G., Baker, A. R., Death, R., Albani, S., Mahowald, N., Krom, M. D., Poul- 
ton, S. W., Wadham, J., and Tranter, M.: Potentially bioavailable iron delivery by iceberg-hosted sediments and atmospheric dust to the polar oceans, Biogeosciences, 13, 3887-3900, https://doi.org/10.5194/bg-13-3887-2016, 2016.

Ravel, B. and Newville, M.: ATHENA, ARTEMIS, HEPHAESTUS: data analysis for X-ray absorption spectroscopy using IFEFFIT, J. Synchrotron Radiat., 12, 537-541, https://doi.org/10.1107/S0909049505012719, 2005.

Reed, B. E., Peters, D. M., McPheat, R., Smith, A. J. A., and Grainger, R. G.: Mass extinction spectra and size distribution measurements of quartz and amorphous silica aerosol at $0.33-19 \mu \mathrm{m}$ compared to modelled extinction using Mie, CDE, and T-matrix theories, J. Quant. Spectrosc. Ra., 199, 52-65, https://doi.org/10.1016/j.jqsrt.2017.05.011, 2017.

Rocha-Lima, A., Martins, J. V., Remer, L. A., Krotkov, N. A., Tabacniks, M. H., Ben-Ami, Y., and Artaxo, P.: Optical, microphysical and compositional properties of the Eyjafjallajökull volcanic ash, Atmos. Chem. Phys., 14, 10649-10661, https://doi.org/10.5194/acp-14-10649-2014, 2014.

Ryan-Keogh, T. J., Macey, A. I., Nielsdottir, M. C., Lucas, M. I., Steigenberger, S. S., Stinchcombe, M. C., Achterberg, E. P., Bibby, T. S., and Moore, C. M.: Spatial and temporal development of phytoplankton iron stress in relation to bloom dynamics in the high-latitude North Atlantic Ocean, Limnol. Oceanogr., 58, 533-545, https://doi.org/10.4319/lo.2013.58.2.0533, 2013.

Scheuvens, D. and Kandler, K.: On composition, morphology, and size distribution of airborne mineral dust, in: Mineral Dust, Springer, 15-49, 2014.

Scheuvens, D., Schutz, L., Kandler, K., Ebert, M., and Weinbruch, S.: Bulk composition of northern African dust and its source sediments - A compilation, Earth-Sci. Rev., 116, 170194, https://doi.org/10.1016/j.earscirev.2012.08.005, 2013.

Schroth, A. W., Crusius, J., Sholkovitz, E. R., and Bostick, B. C.: Iron solubility driven by speciation in dust sources to the ocean, Nat. Geosci., 2, 337-340, https://doi.org/10.1038/ngeo501, 2009.

Schroth, A. W., Crusius, J., Gasso, S., Moy, C. M., Buck, N. J., Resing, J. A., and Campbell, R. W.: Atmospheric deposition of glacial iron in the Gulf of Alaska impacted by the position of the Aleutian Low, Geophys. Res. Lett., 44, 5053-5061, https://doi.org/10.1002/2017g1073565, 2017.

Schumann, U., Weinzierl, B., Reitebuch, O., Schlager, H., Minikin, A., Forster, C., Baumann, R., Sailer, T., Graf, K., Mannstein, H., Voigt, C., Rahm, S., Simmet, R., Scheibe, M., Lichtenstern, M., Stock, P., Rüba, H., Schäuble, D., Tafferner, A., Rautenhaus, M., Gerz, T., Ziereis, H., Krautstrunk, M., Mallaun, C., Gayet, J.F., Lieke, K., Kandler, K., Ebert, M., Weinbruch, S., Stohl, A., Gasteiger, J., Groß, S., Freudenthaler, V., Wiegner, M., Ansmann, A., Tesche, M., Olafsson, H., and Sturm, K.: Airborne observations of the Eyjafjalla volcano ash cloud over Europe during air space closure in April and May 2010, Atmos. Chem. Phys., 11, 2245-2279, https://doi.org/10.5194/acp-11-2245-2011, 2011.

Shao, L. Y., Li, W. J., Yang, S. S., Shi, Z., and Lu, S. L.: Mineralogical characteristics of airborne particles collected in Beijing during a severe Asian dust storm period in spring 2002, Sci. China Ser. D, 50, 953-959, https://doi.org/10.1007/s11430-007-00357, 2007.

Shi, Z., Shao, L. T., Jones, T. P., and Lu, S. L.: Microscopy and mineralogy of airborne particles collected during severe dust storm episodes in Beijing, China, J. Geophys. Res.-Atmos., 110, D01303, https://doi.org/10.1029/2004jd005073, 2005.

Shi, Z., Krom, M. D., Bonneville, S., Baker, A. R., Jickells, T. D., and Benning, L. G.: Formation of iron nanoparticles and increase in iron reactivity in the mineral dust during simulated cloud processing, Environ. Sci. Technol., 43, 6592-6596, https://doi.org/10.1021/es901294g, 2009.

Shi, Z., Bonneville, S., Krom, M. D., Carslaw, K. S., Jickells, T. D., Baker, A. R., and Benning, L. G.: Iron dissolution kinetics of mineral dust at low $\mathrm{pH}$ during simulated atmospheric processing, Atmos. Chem. Phys., 11, 995-1007, https://doi.org/10.5194/acp11-995-2011, 2011a.

Shi, Z., Krom, M. D., Bonneville, S., Baker, A. R., Bristow, C., Drake, N., Mann, G., Carslaw, K., McQuaid, J. B., Jickells, T., and Benning, L. G.: Influence of chemical weathering and aging of iron oxides on the potential iron solubility of Saharan dust during simulated atmospheric processing, Global Biogeochem. Cy., 25, GB2010, https://doi.org/10.1029/2010gb003837, 2011b.

Shi, Z. B., Woodhouse, M. T., Carslaw, K. S., Krom, M. D., Mann, G. W., Baker, A. R., Savov, I., Fones, G. R., Brooks, B., Drake, N., Jickells, T. D., and Benning, L. G.: Minor effect of physical size sorting on iron solubility of transported mineral dust, Atmos. Chem. Phys., 11, 8459-8469, https://doi.org/10.5194/acp11-8459-2011, 2011.

Shi, Z., Krom, M. D., Jickells, T. D., Bonneville, S., Carslaw, K. S., Mihalopoulos, N., Baker, A. R., and Benning, L. G.: Impacts on iron solubility in the mineral dust by processes in the source region and the atmosphere: A review, Aeolian Res., 5, 21-42, https://doi.org/10.1016/j.aeolia.2012.03.001, 2012.

Shi, Z., Krom, M. D., Bonneville, S., and Benning, L. G.: Atmospheric processing outside clouds increases soluble iron in mineral dust, Environ. Sci. Technol., 49, 1472-1477, https://doi.org/10.1021/es504623x, 2015.

Sokolik, I. N. and Toon, O. B.: Incorporation of mineralogical composition into models of the radiative properties of mineral aerosol from UV to IR wavelengths, J. Geophys. Res.-Atmos., 104, 9423-9444, https://doi.org/10.1029/1998jd200048, 1999.

Song, Y. G., Chen, X. L., Qian, L. B., Li, C. X., Li, Y., Li, X. X., Chang, H., and An, Z. S.: Distribution and composition of loess sediments in the Ili Basin, Central Asia, Quaternary Int., 334, 61-73, https://doi.org/10.1016/j.quaint.2013.12.053, 2014.

Stockdale, A., Krom, M. D., Mortimer, R. J., Benning, L. G., Carslaw, K. S., Herbert, R. J., Shi, Z., Myriokefalitakis, S., Kanakidou, M., and Nenes, A.: Understanding the nature of atmospheric acid processing of mineral dusts in supplying bioavailable phosphorus to the oceans, P. Natl. Acad. Sci. USA, 113, 14639-14644, https://doi.org/10.1073/pnas.1608136113, 2016.

Takahashi, Y., Higashi, M., Furukawa, T., and Mitsunobu, S.: Change of iron species and iron solubility in Asian dust during the long-range transport from western China to Japan, Atmos. Chem. Phys., 11, 11237-11252, https://doi.org/10.5194/acp-1111237-2011, 2011.

Tang, M. J., Cziczo, D. J., and Grassian, V. H.: Interactions of Water with Mineral Dust Aerosol: Water Adsorption, Hygroscopicity, Cloud Condensation, and Ice Nucleation, Chem. Rev., 116, 4205-4259, https://doi.org/10.1021/acs.chemrev.5b00529, 2016. 
Toby, B. H.: $\mathrm{R}$ factors in Rietveld analysis: How good is good enough?, Powder Diffr., 21, 67-70, https://doi.org/10.1154/1.2179804, 2006.

Toledano, C., Bennouna, Y., Cachorro, V., de Galisteo, J. P. O., Stohl, A., Stebel, K., Kristiansen, N. I., Olmo, F. J., Lyamani, H., Obregon, M. A., Estelles, V., Wagner, F., Baldasano, J. M., Gonzalez-Castanedo, Y., Clarisse, L., and de Frutos, A. M.: Aerosol properties of the Eyjafjallajökull ash derived from sun photometer and satellite observations over the Iberian Peninsula, Atmos. Environ., 48, 22-32, https://doi.org/10.1016/j.atmosenv.2011.09.072, 2012.

Urupina, D., Lasne, J., Romanias, M. N., Thiery, V., DagssonWaldhauserova, P., and Thevenet, F.: Uptake and surface chemistry of $\mathrm{SO}_{2}$ on natural volcanic dusts, Atmos. Environ., 217, 116942, https://doi.org/10.1016/j.atmosenv.2019.116942, 2019.

Vergara-Temprado, J., Miltenberger, A. K., Furtado, K., Grosvenor, D. P., Shipway, B. J., Hill, A. A., Wilkinson, J. M., Field, P. R., Murray, B. J., and Carslaw, K. S.: Strong control of Southern Ocean cloud reflectivity by icenucleating particles, P. Natl. Acad. Sci. USA, 115, 2687-2692, https://doi.org/10.1073/pnas.1721627115, 2018.

Viollier, E., Inglett, P. W., Hunter, K., Roychoudhury, A. N., and Van Cappellen, P.: The ferrozine method revisited: $\mathrm{Fe}(\mathrm{II}) / \mathrm{Fe}(\mathrm{III})$ determination in natural waters, Appl. Geochem., 15, 785-790, https://doi.org/10.1016/s0883-2927(99)00097-9, 2000.

Vogel, A., Diplas, S., Durant, A. J., Azar, A. S., Sunding, M. F., Rose, W. I., Sytchkova, A., Bonadonna, C., Kruger, K., and Stohl, A.: Reference data set of volcanic ash physicochemical and optical properties, J. Geophys. Res.-Atmos., 122, 94859514, https://doi.org/10.1002/2016jd026328, 2017.

Wang, J., Doussin, J. F., Perrier, S., Perraudin, E., Katrib, Y., Pangui, E., and Picquet-Varrault, B.: Design of a new multi-phase experimental simulation chamber for atmospheric photosmog, aerosol and cloud chemistry research, Atmos. Meas. Tech., 4, 2465-2494, https://doi.org/10.5194/amt-4-2465-2011, 2011.

Weinzierl, B., Sauer, D., Minikin, A., Reitebuch, O., Dahlkotter, F., Mayer, B., Emde, C., Tegen, I., Gasteiger, J., Petzold, A., Veira, A., Kueppers, U., and Schumann, U.: On the visibility of airborne volcanic ash and mineral dust from the pilot's perspective in flight, Phys. Chem. Earth, 45-46, 87-102, https://doi.org/10.1016/j.pce.2012.04.003, 2012.
Wilke, M., Farges, F., Petit, P. E., Brown, G. E., and Martin, F.: Oxidation state and coordination of $\mathrm{Fe}$ in minerals: An FeK-XANES spectroscopic study, Am. Mineral., 86, 714-730, https://doi.org/10.2138/am-2001-5-612, 2001.

Winton, V. H. L., Edwards, R., Delmonte, B., Ellis, A., Andersson, P. S., Bowie, A., Bertler, N. A. N., Neff, P., and Tuohy, A.: Multiple sources of soluble atmospheric iron to Antarctic waters, Global Biogeochem. Cy., 30, 421-437, https://doi.org/10.1002/2015gb005265, 2016.

Wittmann, M., Groot Zwaaftink, C. D., Steffensen Schmidt, L., Guðmundsson, S., Pálsson, F., Arnalds, O., Björnsson, H., Thorsteinsson, T., and Stohl, A.: Impact of dust deposition on the albedo of Vatnajökull ice cap, Iceland, The Cryosphere, 11, 741-754, https://doi.org/10.5194/tc-11-741-2017, 2017.

Wolff-Boenisch, D., Gislason, S. R., and Oelkers, E. H.: The effect of crystallinity on dissolution rates and $\mathrm{CO}_{2}$ consumption capacity of silicates, Geochim. Cosmochim. Ac., 70, 858-870, https://doi.org/10.1016/j.gca.2005.10.016, 2006.

Yoshida, A., Moteki, N., Ohata, S., Mori, T., Tada, R., Dagsson-Waldhauserová, P., and Kondo, Y.: Detection of light-absorbing iron oxide particles using a modified singleparticle soot photometer, Aerosol Sci. Technol., 50, 1-4, https://doi.org/10.1080/02786826.2016.1146402, 2016.

Zhang, X. L., Wu, G. J., Zhang, C. L., Xu, T. L., and Zhou, Q. Q.: What is the real role of iron oxides in the optical properties of dust aerosols?, Atmos. Chem. Phys., 15, 12159-12177, https://doi.org/10.5194/acp-15-12159-2015, 2015.

Zubko, N., Munoz, O., Zubko, E., Gritsevich, M., Escobar-Cerezo, J., Berg, M. J., and Peltoniemi, J.: Light scattering from volcanicsand particles in deposited and aerosol form, Atmos. Environ., 215, 116813, https://doi.org/10.1016/j.atmosenv.2019.06.051, 2019. 